\title{
Aquatic Surveys and Assessment within the Middle Powder River Watershed
}

Prepared for the Bureau of Land Management, Miles City FO

ESA010009 Task Order \#28

by

David M. Stagliano

Aquatic Ecologist

April 2006
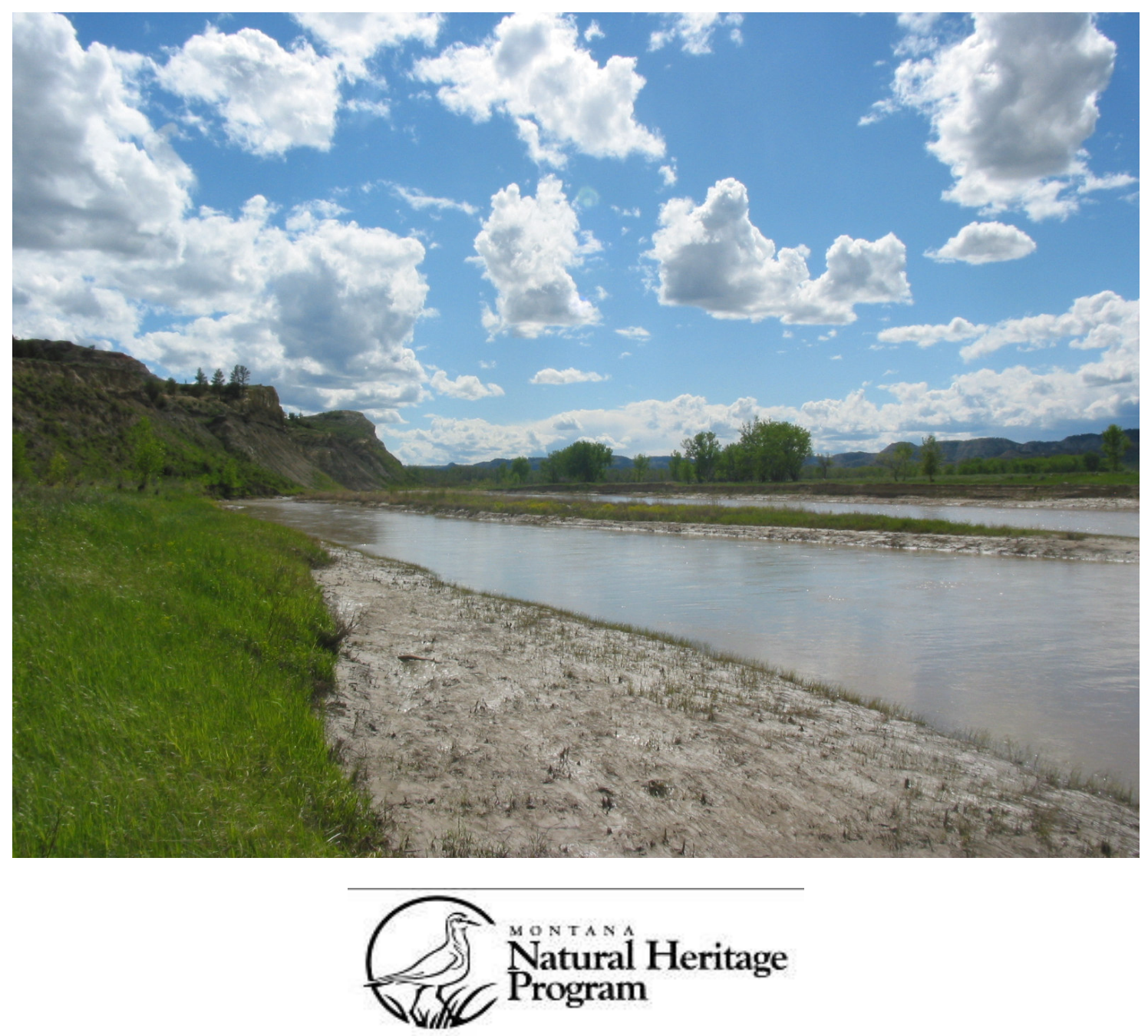

Natural Resource Information System

Montana State Library 


\section{Aquatic Assessment Executive Summary}

Project goals of the Aquatic Surveys and Assessment of the Middle Powder Watershed were to: 1) set up integrator sites, 2) assess aquatic community baseline data, 3) identify and interpret key watershed indicators (against reference condition standards) to determine aquatic condition status and trends before the development of CBM wells in the immediate watershed (Pers. comm. with Joseph Platz, 3/5/2005). This report represents the local reach-scale, aquatic portion of the larger watershed assessment that will use an ecological community context to help qualify watershed health and to identify focal concerns in the region. Inventory work occurred on BLM lands where possible to enable informed management decisions at a watershed planning scale. Fish, water quality parameters, habitat and macroinvertebrate samples were taken at 5 mainstem Powder River and one tributary site in the Middle Powder Watershed in Montana for this BLM assessment. One mainstem site was sampled twice temporally for fish and an additional macroinvertebrate sample was collected from a spring-supported reach of Bloom Creek.

Macroinvertebrate Communities: Overall, 59 taxa were reported from all mainstem sites. Average macroinvertebrate taxa richness per site was 23.4. Paired macroinvertebrate samples taken at each mainstem site using two EMAP sampling protocols were in agreement for ranking all five Powder River sites as non-impaired, with the DEQ MMI index scores $>37$. However, the two protocols yielded very different community composition measures and the within-site sampling method variability was greater than similar-method across site variability. Within-site percent and taxa similarity values between the two EMAP protocols were low and ranged from $40 \%$ to $77.6 \%$. To achieve less site/protocol-influenced variability, higher macroinvertebrate numbers and consistency in future biomonitoring, we recommend the EMAP Targeted-Riffle Protocols. Although, the Reach-Wide EMAP samples did pick up 2 of the 5 species of rare sand-dwelling mayflies not sampled with the Targeted-Riffle Protocols.

Fish Communities: Fish surveys were accomplished using the 300m seining protocols developed by Bramblett (2003) for MT Fish, Wildlife and Parks. This protocol seemed to cover most macrohabitats in a reach, but due to the large size of the Powder, rarely encompassed more than one series of riffle/run/pools. Overall, we captured and identified 1299 individuals of 13 fish species (11 natives). Native fish averaged 7 species per site ( 7.5 is the expected reference condition), and 2 sites had the exotic carp and introduced plains killifish, respectively. Fish communities scored relatively low using the IBI (averaging 59.5-fair integrity range), but when using the derived Observed vs. Expected (O/E) values, 4 of 5 sites fell within the 1.2-0.8 unimpaired/good community threshold ranking, one was on the border (0.8) and Site 6 showed some impairment in the community with an $\mathrm{O} / \mathrm{E}$ of 0.66 . The fish $\mathrm{O} / \mathrm{E}$ scores also correlated with the MMI scores across sites better than the IBI. The Sturgeon Chub, a MT species of concern, was only collected at one site and only represented 2 individuals. We recommend including at least 2 riffle/run complexes (skip portions of long monotonous sand reaches) in the $300 \mathrm{~m}$ seining and using the $\mathrm{O} / \mathrm{E}$ scores for integrity analysis.

Community Integrity results from the fish, habitat and macroinvertebrate surveys combined to rank the Powder River reach upstream of Rough Creek (Site 5) the most biologically intact, followed by the Powder River reach @ the Wyoming border (Site 1) and Site (2), the Dry Creek reach. We recommend choosing these as integrator and future monitoring sites. 


\section{Acknowledgements}

We would like to thank The Montana State Office of the Bureau of Land Management (BLM), especially Gayle Sitter, and Joe Platz of the Miles City Field Office for support and funding for the Aquatic Program of the Montana Natural Heritage Program. This project was also partially funded by the ongoing BLM Watershed Assessment Project.

We wish to thank those who assisted us with this project in the water, including field help from Coburn Currier, Support Biologist of the MTNHP and Trixi B. Smith, volunteer helper from Michigan State University. Additional on-site field and logistics help were supplied by Linda Vance and Greg Kudray.

All photos in the report were taken by MTNHP personnel, unless otherwise noted.

\section{TABLE OF CONTENTS}

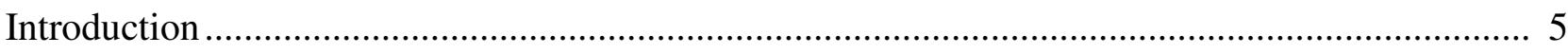

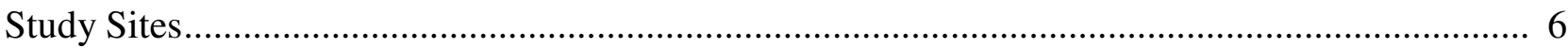

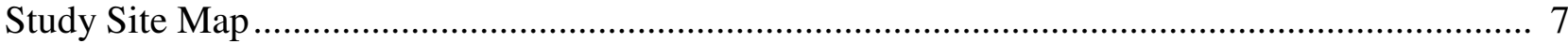

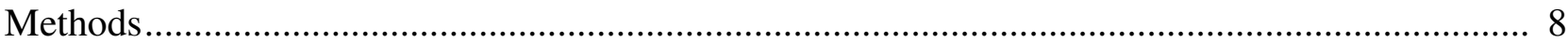

Habitat and Water Quality Collection................................................................................. 8

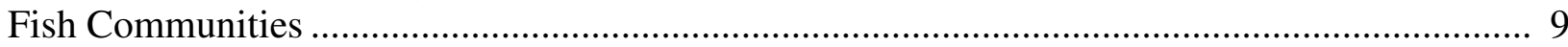

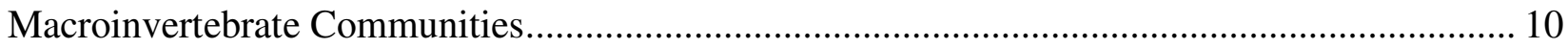

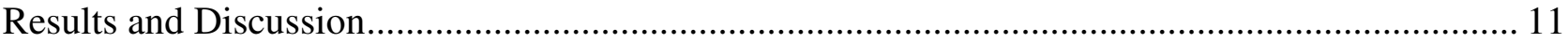

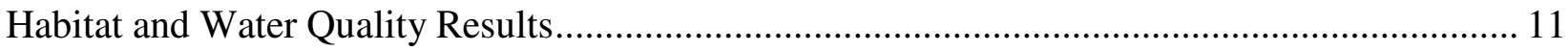

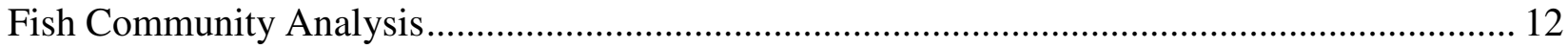

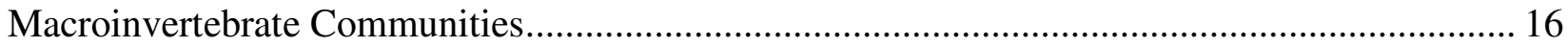

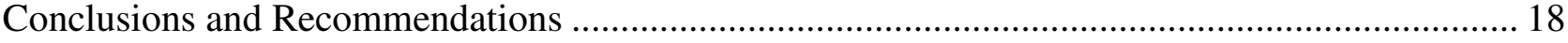

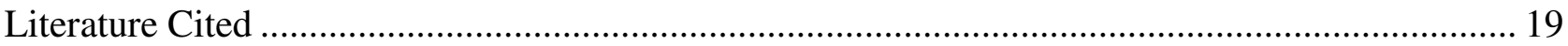

Appendix A. Raw data and IBI metric calculation from fish data collected from Middle Powder Watershed.

Appendix B. Frequencies of fish species occurrence ( $\mathrm{F}$ of $\mathrm{O}$ ) across different segments of the Powder River. All sites includes 2 Wyoming sites @ river mile 225 and 235, all MT sites includes from river mile 220 to the confluence with the Yellowstone

Appendix C. Macroinvertebrate taxa list and abundance at each site, and plains MMI calculation table.

Appendix D. Macroinvertebrate protocol comparisons with Percent Community Similarity and Taxa Similarity per site.

Appendix E. Fish and Macroinvertebrate Community Group Descriptions

\section{List of Figures}

Map 1. Aquatic Sample sites in the Middle Powder River Watershed................................7

Figure 1. Seining the Powder River near the WY border ........................................ 8

Figure 2. Kick Seining a riffle on the Powder River........................................... 
Figure 3. Fish IBI and O/E comparisons at the Powder River sites. Sites 5t1 \& $5 \mathrm{t} 2$ are June and July samples at Site 5, respectively

Figure 4. Cluster analysis of relativized macroinvertebrate abundance data taken with the two EMAP

protocols.............................................................................. 16

Figure 5. Relationship between the habitat scores, Fish O/E and the macroinvertebrate MMI index scores. Impairment thresholds are lines @ 0.8 (O/E) and 37 (MMI)

\section{List of Tables}

Table 1. Fish metrics and classification of fishes captured on the Powder River (2005)................9

Table 2. Impairment determinations from the MMI and O/E (RIVPACS) models......................10

Table 3. Habitat quality scores, physical \& water quality parameters of Middle Powder River sites......11

Table 4. Fish collected from the mainstem Powder River, IBI and O/E index scores.....................12

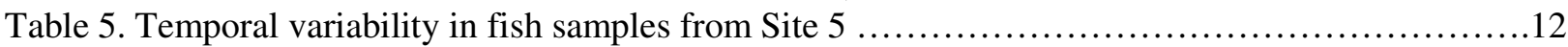

Table 6. Powder River fish samples @ the Wyoming border taken 30 years apart.......................14

Table 7. Cumulative species list and percentage of site occurrences of fish collected on the main-stem Powder River in Montana (0-220 river miles). Asterisk (*) indicates fish species that have not been collected since the 1970's collections..........................................................15 Table 8. Overall macroinvertebrate results, sample date, percent sub-sampled, total taxa richness, number of individuals in the sample, multimetric index score, and impairment status for each stream site........16 


\section{Introduction}

The Powder River is a vast drainage representing one of the last undammed, large prairie river systems in the United States. In this part of southeastern Montana, the landscape through which the Powder flows resembles a virtually natural condition-state of a large prairie river with sweeping meanders across the valley bottom, side channels, oxbows, shifting islands and functional connectedness to the floodplain. The Powder River aquatic ecosystem supports many elements of community function and biological diversity associated with its physical setting, including 25 native fish species (19 in Montana) and numerous species of rare invertebrates. With its specialized aquatic life, the Powder River supports not only a diverse community but represents the sole remnant of a once widespread Great Plains riverine community of fish and invertebrates (Hubert 1993). Prairie rivers and streams are one of the most understudied and endangered aquatic systems in North America (Dodds et al 2004). Furthermore, the Powder River provides substantial habitat for the declining sturgeon chub (MTSOC, species of concern), a species that has been extirpated from much of its historic range (Werdon 1994). In Wyoming, the Powder River was identified by Patton et al. (1998) as supporting an abundance of species adapted to turbid rivers (the flathead chub, Platygobio gracilis; plains minnow, Hybognathus placitus; western silvery minnow, Hybognathus argyritis; river carpsucker, Carpoides carpio, and the channel catfish, Ictalurus punctatus) that have been greatly reduced or eliminated from other drainages. In a previous report, Stagliano (2005) identified the Powder River as the reference standard in its Large Prairie River classification; no other large prairie system in the ecoregion contains the quality and biological integrity of its communities and habitats. The Powder River has been identified as the primary spawning area for the lower Yellowstone River sauger (MTSOC) population (Rehwinkel 1978), as well as other species that migrate from the Yellowstone River to these tributaries to spawn (the blue sucker (Cycleptus elongatus), shovelnose sturgeon (Scaphirhynchus platorhynchus), burbot, and channel catfish)(Backes 1994, Riggs and Gardner 2000).

The invertebrate communities in the Powder River are as rare and specialized as the fishery. Rehwinkel (1978) concluded that the Powder River supported the most unique community of benthic invertebrates in Montana. More recent investigations (2000-2002) by Dan Gustafson (pers comm. 01/12/2006) and this study (2005) indicate that some of these specialized mayflies (Ephemeroptera) are not only rare, but are in decline. Six of these globally rare to uncommon mayfly species (Analetris eximia, Anepeorus rusticus, Raptoheptagenia cruentata, Ametropus neavei, Homoeoneuria alleni, Lachlania saskatchewanensis) will now be included on the 2006 Montana species of concern list (unpublished, Montana Natural Heritage Program 2006). These species were probably once quite common in prairie rivers in the northern Great Plains, but have been eliminated throughout most of their historic range due to impoundments and other anthropogenic river alterations.

The Powder River Basin in Wyoming and Montana is currently undergoing one of the world's largest coalbed natural gas (CBNG) developments with about 12,000 wells in place in 2003, 14,200 in 2005, and up to 70,000 projected over the next 20 to 30 years (Davis and Bramblett, 2006). Coal bed methane mining has the potential to severely disrupt the ecosystem and harm its biota, both in the riparian zone and within the stream itself. The interconnectedness of rivers with their watershed renders any lotic ecosystem vulnerable to threats from human activities 
anywhere in the landscape (Allan et al.1997). Numerous aquatic and fisheries professionals have commented on the consequences of CBM mining within the watershed in an EIS report to the BLM. See expert evaluations at http://www.powderriverbasin.org/cbm/expert_allan.shtml for potential ecological consequences of unrestricted CBM development within the immediate watershed. A recent aquatic task group (ATG) was convened by the BLM to address some of the monitoring and research issues and will undoubtedly perform rigorous scientific investigations before proceeding on a path that will endanger a rare ecosystem.

\section{Powder River Sites}

Per conversation with Joe Platz (5/5/2005), we chose sites along the main-stem Middle Powder River with BLM in-holdings that were easily accessible and would complement USGS monitoring sites (see Map 1):

1) *Large parcels upstream of Moorhead near the WY border where Bradshaw, Bitter and Dry Creeks enter the Powder (either side access, 2 reaches).

2) Downstream of Moorhead where Jenkins Creek enter the Powder (south side access).

3) *Across and downstream from where Bloom Creek enters the Powder (south-side access, Buttermilk Creek).

4) Upstream from where Rough Creek (north) enters the Powder (north-side access)

\begin{tabular}{|l|l|l|l||c||c|}
\hline Site No. & Description & Latitude & Longitude & Elev (ft) & $\begin{array}{c}\text { Date } \\
\text { Sampled }\end{array}$ \\
\hline \hline Powder River 1 & Powder River @ WY border & 45.015037 & -105.90618 & 3415 & $7 / 11 / 2005$ \\
\hline Powder River 2 & Powder River @ Dry Creek & 45.037712 & -105.88085 & 3391 & $7 / 11 / 2005$ \\
\hline Powder River 3 & Powder River @ Jenkins Creek & 45.106189 & -105.83847 & 3314 & $7 / 11 / 2005$ \\
\hline Powder River 6 & Powder River @ Buttermilk Creek & 45.225601 & -105.69058 & 3185 & $7 / 12 / 2005$ \\
\hline Powder River 5t1 & Powder River ups Rough Creek & 45.346674 & -105.53329 & 3105 & $6 / 3 / 2005$ \\
\hline Powder River 5t2 & Powder River ups Rough Creek & 45.346674 & -105.53329 & 3105 & $7 / 12 / 2005$ \\
\hline Bloom Creek & downstream Hailstone Spring & 45.233325 & -105.89855 & 3757 & $5 / 20 / 2005$ \\
\hline
\end{tabular}

Joe Platz and I did site recon in early June and established the 5 mainstem Powder River reaches (with GPS points, flagging and site photos at the 0,300 and $450 \mathrm{~m}$ points). Numerous tributary sites on BLM lands were visited ( 19 stream miles) in the watershed for possible lotic sampling, but were consistently dry. Intermittent Prairie Stream reaches that were visited, but not sampled, included Bitter, Buttermilk, Jenkins, Rough (north \& south), Buffalo, Dry and Maverick Prong of Bloom Creek (see Map 1). One mainstem site (166.2 RM, Site 5 near Rough Creek) was sampled twice temporally for fish.

\section{$\underline{\text { Methods }}$}

Aquatic communities (fish \& macroinvertebrates) and riparian areas were inventoried and assessed using a combination of FWP (fish) and BLM / EPA (macroinvertebrates and habitat assessments) protocols and methodology. Reach lengths were set as a standard $300 \mathrm{~m}$, but to encompass an additional set of riffle macrohabitats for the macroinvertebrate targeted-riffle sampling protocols were extended to $450 \mathrm{~m}$. Information and results from previous inventories, such as those conducted by FW\&P (fish) and the BLM (e.g. PFC Lotic riparian areas) will be integrated into the final Watershed Assessment report. This report will provide a valuable baseline of current watershed health and recommendations for future monitoring efforts. 
Map 1. Aquatic sample sites in the Middle Powder River Watershed.

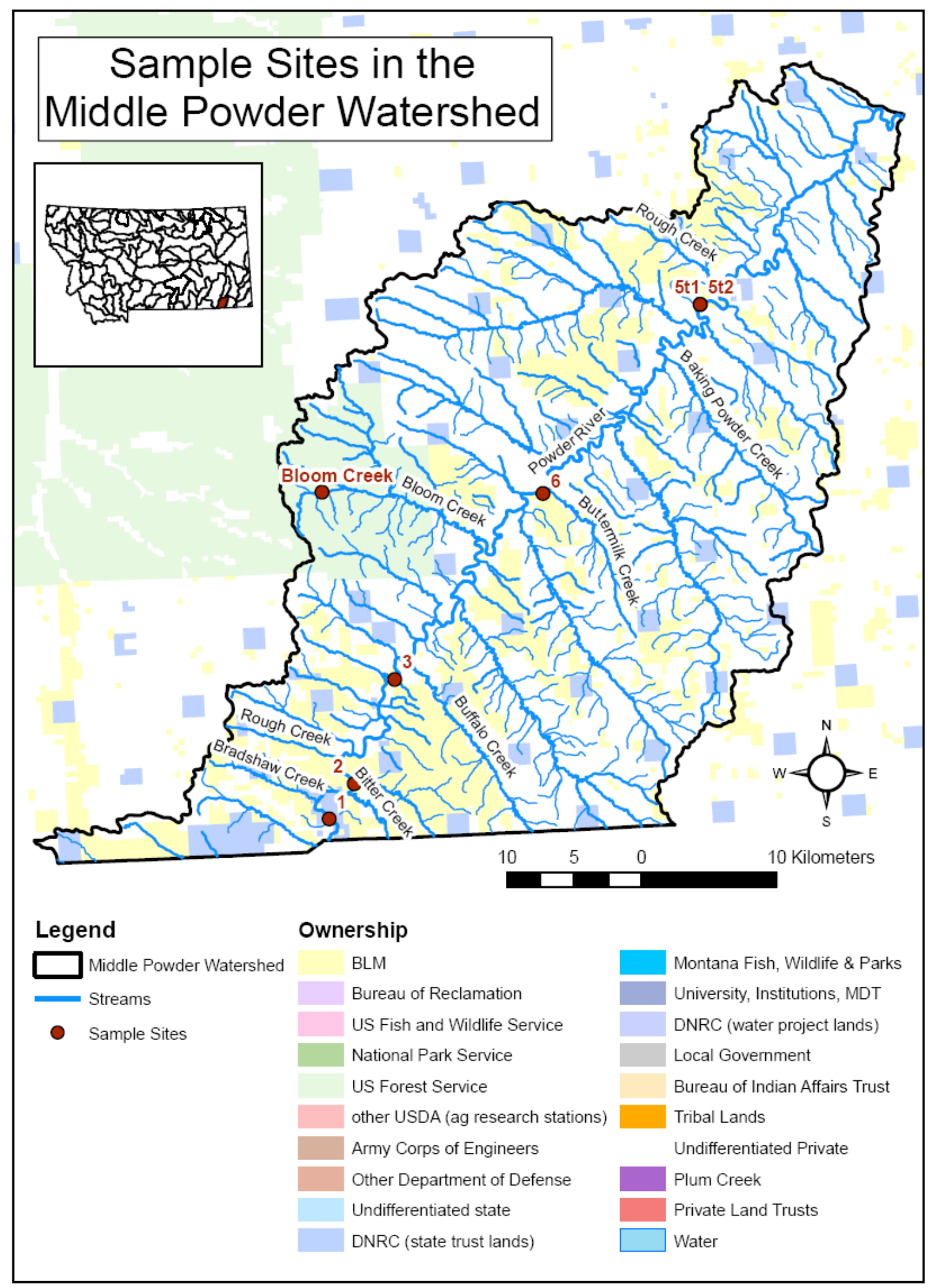




\section{Habitat and Water Quality Collection and Analysis}

A visual rapid habitat assessment (Barbour et al. 1999) based on 10 habitat variables (instream fish cover, epifaunal substrate, pool substrate characterization, pool variability, channel alteration, sediment deposition, channel sinuosity, channel flow status, bank condition, bank vegetative protection, riparian vegetated zone width) was completed for each sampled reach. The habitat quality scoring is based on a maximum score of 200. Additional physical habitat: channel wetted width (in meters), channel depths recorded at $1 / 4,1 / 2$ and $3 / 4$ wetted width at all transects (in centimeters), and substrate (in \% size-class coverage per transect) based on Wollman size-classes were measured at 10 transects spaced 30 meters apart perpendicular to the stream channel. Specific conductivity, $\mathrm{pH}$, water temperature and dissolved oxygen concentration were measured on-site prior to biological sampling with a Yellow Springs Instruments, Inc. model 85 water quality meter calibrated to the higher conductivity level.

\section{Fish Collection and Analysis}

Fish surveys were performed using the $300 \mathrm{~m}$ seining protocols developed by Bramblett (2003) for MT Fish, Wildlife and Parks. This protocol calls for block nets at the upstream and downstream ends of the reach, but the width of the Powder River precluded the use of these. Instead, shallow riffle areas were used as barriers and probably sufficient to prevent fish from escaping while the run \& pool areas were being seined (Figure 1). Shallow riffle areas unable to be seined in the normal fashion because of rock obstructions were "kick-seined" (Figure 2) to capture fish inhabitating this macrohabitat. We used 30ft, $1 / 4$ inch mesh seines to cover most areas across the channel and all macrohabitats within the reach. Fish were transferred to holding buckets, identified to species, enumerated in the field, examined for external anomalies (e.g. deformities, eroded fins, lesions, and tumors), and then released. Young-of-the-year fish less than 20 millimeters in length were noted on the field sheet (not included in the totals), and released. Voucher specimens were only taken in the case of uncertain field identifications of the silvery minnows, Hybognathus spp., which were preserved in $10 \%$ buffered formalin and identified in the lab. Vouchers will be submitted to the Montana State University fish collection.
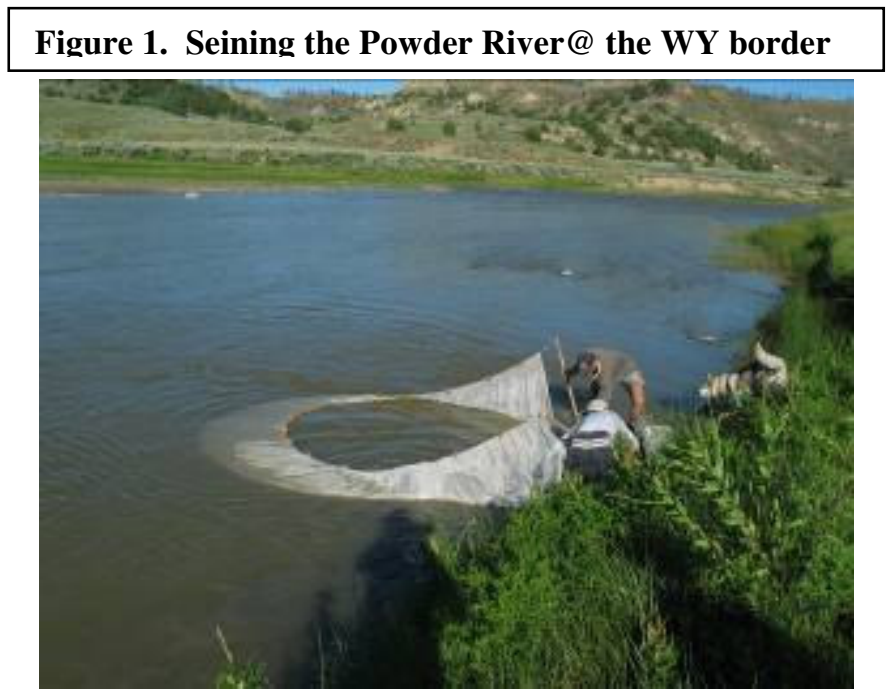

Figure 2. Kick Seining a riffle on the Powder River

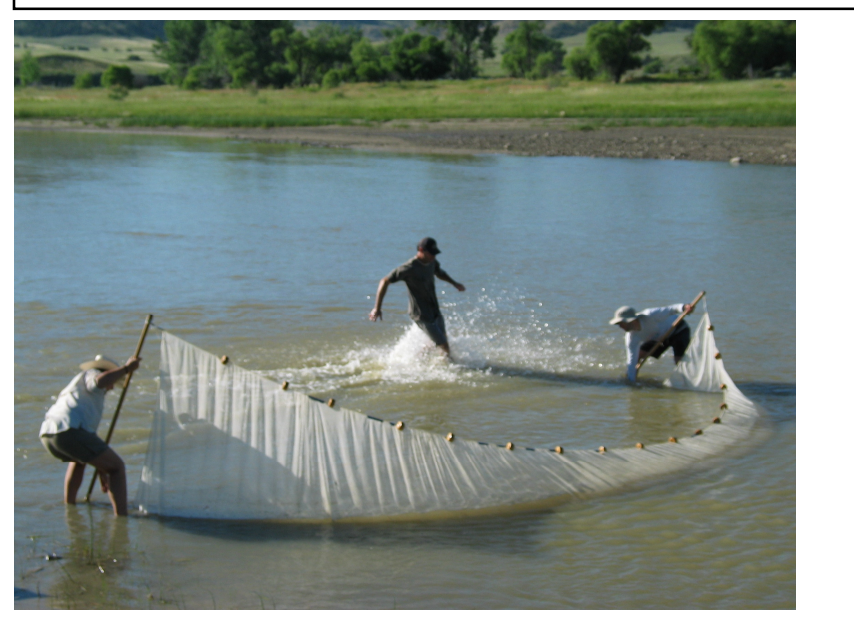

Analysis of the sampled fish communities used Integrated Biotic Indices (IBI) (Bramblett et. al 2005) and derived Observed/Expected (O/E) Fish Models (Stagliano 2005) to detect impairment in the biological integrity of the sites. The IBI involved calculation of a series of metrics 
evaluating different attributes of the community (Table 1). Because fish taxa richness is expected to be directly proportional to watershed size, we used an average catchment area for this reach $\left(20,962 \mathrm{~km}^{2}\right)$ based at the Moorehead gaging station. The metrics allowed calculation of an overall score between 0 and 100. Bramblett et al. (2005) did not propose threshold criteria for good, fair, and poor biological integrity for these scores. Therefore, we applied commonly used criteria 75 to 100 indicating good to excellent biological integrity, 25 to $74 \%$ indicated fair biological integrity, and $<25 \%$ indicating poor biological integrity.

Table 1. Fish metrics and classification of fishes captured on the Powder River (2005).

\begin{tabular}{|c|c|c|c|c|c|c|}
\hline Species & Scientific Name & Trophic* & $\begin{array}{l}\text { Feeding } \\
\text { Habitat } \dagger\end{array}$ & $\begin{array}{c}\text { Litho-obligate } \\
\text { Reproductive } \\
\text { Guild }+\end{array}$ & Tol*** & $\begin{array}{c}\text { Origin } \\
\dagger \dagger\end{array}$ \\
\hline \multicolumn{7}{|l|}{ Hiodontidae } \\
\hline Goldeye & Hiodon alosoides & IN & WC & $\mathrm{LO}$ & INT & $\mathrm{N}$ \\
\hline \multicolumn{7}{|l|}{ Catostomidae } \\
\hline River carpsucker & Carpiodes carpio & $\mathrm{OM}$ & $\mathrm{BE}$ & LO & MOD & $\mathrm{N}$ \\
\hline Shorthead Redhorse & $\begin{array}{l}\text { Moxostoma } \\
\text { macroledidotum }\end{array}$ & IN & $\mathrm{BE}$ & $\mathrm{LO}$ & MOD & $\mathrm{N}$ \\
\hline \multicolumn{7}{|l|}{ Cyprinidae } \\
\hline Common carp & Cyprinus carpio & $\mathrm{OM}$ & $\mathrm{BE}$ & & TOL & I \\
\hline Flathead Chub & Platygobio gracilis & IN & GE & & MOD & $\mathrm{N}$ \\
\hline Longnose dace & Rhinichthys cataractae & IN & $\mathrm{BE}$ & $\mathrm{LO}$ & INT & $\mathrm{N}$ \\
\hline Plains minnow & Hybognathus placitus & $\mathrm{HB}$ & $\mathrm{BE}$ & & MOD & $\mathrm{N}$ \\
\hline $\begin{array}{l}\text { Western silvery } \\
\text { minnow }\end{array}$ & Hybognathus argyritis & $\mathrm{HB}$ & $\mathrm{BE}$ & & MOD & $\mathrm{N}$ \\
\hline Sand shiner & Notropis stramineus & $\mathrm{OM}$ & GE & $\mathrm{LO}$ & MOD & $\mathrm{N}$ \\
\hline Sturgeon Chub & Macrhybopsis gelida & IN & $\mathrm{BE}$ & LO & INT & $\mathrm{N}$ \\
\hline \multicolumn{7}{|l|}{ Cyprinidontidae } \\
\hline $\begin{array}{l}\text { Plains Killifish } \\
\text { Ictaluridae }\end{array}$ & Fundulus kansae & OM & GE & & TOL & I \\
\hline Channel catfish & Ictalurus punctatus & IC & $\mathrm{BE}$ & $\mathrm{TR}^{\S}$ & MOD & $\mathrm{N}$ \\
\hline Stonecat & Noturus flavus & $\mathrm{IC}$ & $\mathrm{BE}$ & $\mathrm{LO}$ & INT & $\mathrm{N}$ \\
\hline
\end{tabular}

$\mathrm{HB}=$ herbivore $(>90 \%$ plants or detritus $) ; \mathrm{IC}=$ invertivore/carnivore $(>25 \%$ both invertebrates and vertebrates $)$ IN $=$ invertivore; OM = omnivore(25-90\% plants or detritus)

$\dagger \mathrm{BE}=$ benthic; $\mathrm{GE}=$ generalist; WC = water column: Brown (1971); Scott and Crossman (1973); Becker (1983)

$\mp$ Scott and Crossman (1973); Pflieger (1997); Barbour et al. (1999)

$\S$ Tolerant reproductive strategists are not litho-obligates, use parental care @ spawning site: Scott and Crossman (1973); Pflieger (1997)

** INT = intolerant; MOD = moderately tolerant: TOL = tolerant; Barbour et al. (1999);

$\dagger \dagger \mathrm{N}=$ native; I - introduced; Brown (1971); Holton and Johnson (2003)

Derivation of the expected fish communities is performed by identifying the frequency of occurrence that a species has at a site classified in a reference condition and summing the frequencies across all fish species of the community (see Appendix B). The O/E (Observed taxa of an evaluated site/Expected Taxa for a reference site) model is a direct measure of the biological community. It compares the taxa that are expected at a site (carp and introduced fish are never "expected" and given zeros) with the actual taxa that were found when the site was sampled. In some cases, it is more ecologically meaningful than the IBI, but not always. 


\section{Macroinvertebrate Collection and Analysis}

Paired macroinvertebrate samples taken at each site allowed a comparison of two differing sampling protocols. The two methods utilized were the EMAP_Targeted Riffle (8 composited surbers) and the EMAP_Reach-Wide Multi-habitat. These samples were taken in July 2005 following the standard EMAP protocols (Lazorchak 1998), and processed (sorting, identification, and data analysis) by David Stagliano at the Montana Natural Heritage Program Helena lab. Macroinvertebrates were identified to the taxonomic level specified by Montana DEQ and biological metrics were calculated from the data. Montana Department of Environmental Quality's newest multimetric macroinvertebrate (MMI) protocols (Jessup et al. 2005, DEQ 2006) were used to analyze the macroinvertebrate samples. Metric results were then scored using the Montana DEQ bioassessment criteria and each sample categorized as non-impaired or impaired according to threshold values.

The macroinvertebrate MMI score is based upon a series of metrics that measure attributes of benthic macroinvertebrate communities regarding condition changes to a stream system (in the form of pollution or pollutants). The invertebrate metrics include: EPT Taxa Richness (Score = EPT richness/14*100): Ephemeroptera, Plecoptera \&Trichoptera taxa; Percent Tanypodinae $($ Score $=$ PercentTanypodinae $/ \mathbf{1 0} * \mathbf{1 0 0})$ : Tanypodinae is a subfamily within the family Chironomidae; Percent Orthocladiinae of Chironomidae $($ Score $=(100$-percent Orthocladiinae of Chironomidae $/ 100$ ) $* 100$ ); Predator Taxa Richness (Score $=$ number of predator taxa/9*100); Percent Collectors and Filterers (Score $=(100-$ percent collectors and filterers/65)*100): This metric measures the relative abundance of collector and filterer taxa in the sample. The index score represents the condition of the macroinvertebrate community at the time the sample was collected within that past year. If the index score is below the impairment threshold, the individual metrics can be used to provide insight as to why the communities are different from the reference condition (Barbour et. al 1999, Jessup et. al. 2005). The results from the eastern plains index metrics are averaged to obtain the final index score. The impairment threshold set by MT DEQ is $\mathbf{3 7}$ for the eastern plains stream index (Table 2).

Table 2. Impairment determinations from the MMI and O/E (RIVPACS) models (taken from Jessup 2005, Feldman 2006).

\begin{tabular}{l|l|l|l} 
Ecoregion & RIVPACS & MMI & Impairment Determination \\
\hline \hline Mountain & $\geq 0.8$ or $\leq 1.2$ & $\geq 63$ & Not impaired \\
& $<0.8$ or $>1.2$ & $<63$ & Impaired \\
& & & \\
Low Valley & $\geq 0.8$ or $\leq 1.2$ & $\geq 48$ & Not impaired \\
& $<0.8$ or $>1.2$ & $<48$ & Impaired \\
& & & \\
Eastern Plains & $\geq 0.8$ or $\leq 1.2$ & $\geq 37$ & Not impaired \\
& $<0.8$ or $>1.2$ & $<37$ & Impaired
\end{tabular}




\section{RESULTS AND DISCUSSION}

\section{Habitat and Water Quality Results and Analysis}

Powder River Sites 1 and 5 scored highest in habitat quality with both the BLM and EPA RBP assessment protocols, representing $70 \% \& 85 \%$ of the best possible score, respectively (Table 3 ). Site 5 also had the highest number of recorded channel depths $>50 \mathrm{~cm}$ indicating ample deep holding areas for fish. Powder River Site 3 scored lowest in both habitat assessment scores despite having the second highest number of channel depths $>50 \mathrm{~cm}$, unfortunately many of these deep areas had unsuitable, unconsolidated substrate (silt, fine sand) to be considered optimum fish habitat. Temperature increases and dissolved $\mathrm{O}_{2}$ (DO) decreases progressing through the day can be seen with sites $1,2 \& 3$. Site 1 was sampled in the morning and by the time Site 3 was sampled in the late afternoon water temperatures increased $>8$ degrees $\mathrm{C}$ and DO decreased by $>1 \mathrm{mg} / \mathrm{l}$. With dissolved oxygen levels already fairly low, a $1 \mathrm{mg} / \mathrm{l}$ decrease through the day can probably become stressful to some fish species.

Table 3. Habitat quality scores, physical \& water quality parameters of Middle Powder River sites.

\begin{tabular}{|c|c|c|c|c|c|c|c|c|c|}
\hline Site No. & $\begin{array}{c}\text { BLM } \\
\text { Site } \\
\text { Score }\end{array}$ & $\begin{array}{c}\text { EPA } \\
\text { RBP } \\
\text { Score }\end{array}$ & $\begin{array}{c}\text { Avg } \\
\text { wetted } \\
\text { width } \\
\text { (m) }\end{array}$ & \begin{tabular}{|c|} 
Avg \\
channel \\
depth \\
$(\mathbf{c m})$
\end{tabular} & $\begin{array}{c}\# \mathrm{CD}^{1} \\
>50 \mathrm{~cm}\end{array}$ & $\begin{array}{c}\mathbf{H}_{2} \mathbf{O} \\
\text { Temp } \\
\left({ }^{\circ} \mathbf{C}\right)\end{array}$ & ph & Cond* & $\mathbf{D O}^{\wedge}$ \\
\hline$\overline{\text { Powder River } 1}$ & 17 & $\overline{170}$ & $\overline{42.4}$ & $\overline{38.2}$ & 8.0 & 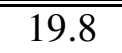 & 8.5 & $\overline{1120}$ & 4.4 \\
\hline Powder River 2 & 15 & 164 & 38.5 & 38.5 & 7.0 & 24.5 & 8.5 & 1140 & 3.7 \\
\hline Powder River 3 & 14 & 139 & 44.0 & 43.5 & 15.0 & 27.9 & 8.6 & 1130 & 3.3 \\
\hline Powder River 6 & 14 & 146 & 45.0 & 30.8 & 7.0 & 21.9 & 8.4 & 1222 & 4.8 \\
\hline Powder River 5t1 & 16 & 172 & 41.0 & na & na & 15.3 & 8.2 & 1180 & 8.0 \\
\hline Powder River 5t2 & 16 & 172 & 37.0 & 39.5 & 16.0 & 27.7 & 8.4 & 1350 & 4.7 \\
\hline Bloom Creek & 12 & 137 & 1.9 & 10.5 & 0.0 & 16.5 & 8.1 & 680 & 4.0 \\
\hline
\end{tabular}

$\mathrm{CD}^{1-}$ channel depths reflecting deep run or pool areas

*Conductivity--microsiemens/cm

${ }^{\wedge}$ Dissolved Oxygen---mg/l

na-data not taken on this date

\section{Fish Community Results and Analysis}

Thirteen species of fish (11 natives) were identified from 1299 individuals across the 6 samples at 5 mainstem Powder River sites (Table 4). No fish were observed or collected at the Bloom Creek upstream site. Native fish averaged 7 species per site and represented members of 2 species group assemblages, the Medium Warmwater River and the Core Prairie Stream Assemblage (Stagliano 2005, Appendix E). Sites 1 and 5 had the highest average species richness with 8 , and no non-native species were sampled. Site 5 was also the only site where we collected the Sturgeon Chub (MT SOC) on both sampling periods, June and July, represented by 2 and 1 individuals, respectively (Table 5). 
Table 4. Fish collected from the mainstem Powder River, IBI and $\mathrm{O} / \mathrm{E}$ index scores.

\begin{tabular}{lcccccc}
\hline Powder River & Site $\mathbf{1}$ & Site 2 & Site 3 & Site $\mathbf{6}$ & Site 5t1 & Site 5t2 \\
\hline River Mile & 219 & 215.4 & 206.6 & 186.9 & 166.2 & 166.2 \\
Collection date: & $7 / 11 / 05$ & $7 / 11 / 05$ & $7 / 11 / 05$ & $7 / 12 / 05$ & $6 / 3 / 05$ & $7 / 12 / 05$ \\
\hline Channel Catfish & 3 & 4 & 1 & 0 & 11 & 2 \\
Common Carp & 0 & 2 & 0 & 0 & 0 & 0 \\
Flathead Chub & 96 & 47 & 30 & 26 & 116 & 46 \\
Goldeye & 3 & 0 & 2 & 0 & 0 & 3 \\
Longnose Dace & 3 & 2 & 3 & 0 & 62 & 1 \\
Plains Minnow & 12 & 0 & 3 & 1 & 5 & 1 \\
Plains Killifish & 0 & 0 & 0 & 2 & 0 & 0 \\
River Carpsucker & 1 & 0 & 0 & 1 & 0 & 3 \\
Sand Shiner & 305 & 97 & 19 & 47 & 97 & 224 \\
Shorthead Redhorse & 1 & 0 & 0 & 0 & 0 & 0 \\
Stonecat & 0 & 2 & 0 & 0 & 0 & 0 \\
Sturgeon Chub* & 0 & 0 & 0 & 0 & 2 & 1 \\
Western Silvery Minnow & 0 & 2 & 2 & 1 & 6 & 1 \\
Total \# species & $\mathbf{8}$ & $\mathbf{7}$ & $\mathbf{7}$ & $\mathbf{6}$ & $\mathbf{7}$ & $\mathbf{9}$ \\
Native Species & $\mathbf{8}$ & $\mathbf{6}$ & $\mathbf{7}$ & $\mathbf{5}$ & $\mathbf{7}$ & $\mathbf{9}$ \\
Total Individuals & $\mathbf{4 2 4}$ & $\mathbf{1 5 6}$ & $\mathbf{6 0}$ & $\mathbf{7 8}$ & $\mathbf{2 9 9}$ & $\mathbf{2 8 2}$ \\
IBI & $\mathbf{6 4}$ & $\mathbf{5 6}$ & $\mathbf{5 7}$ & $\mathbf{5 2}$ & $\mathbf{6 1}$ & $\mathbf{6 7}$ \\
\hline O/E converted to \% & $\mathbf{1 0 7}$ & $\mathbf{8 0}$ & $\mathbf{9 3}$ & $\mathbf{6 6}$ & $\mathbf{9 3}$ & $\mathbf{1 2 0}$ \\
\hline
\end{tabular}

At Site 5, we can view the temporal shift in fish communities from June to July with substantial decreases in the longnose dace, flathead chubs and channel catfish and an increase in sand shiners, goldeyes and river carpsuckers (Table 5). This widely fluctuating community structure (with only $51 \%$ similarity between dates) is characteristic of variable flow conditions and migratory spawning fish species.

The longnose dace, flathead chubs, sand shiners and channel catfish all showed signs of

Table 5. Temporal variability in fish samples from Site 5

\begin{tabular}{lcc} 
Powder River (Site 5) & $6 / 3 / 2005$ & $7 / 11 / 2005$ \\
\hline Channel Catfish & 11 & 1 \\
Goldeye & 0 & 3 \\
Longnose Dace & 62 & 1 \\
Flathead Chub & 116 & 46 \\
Sturgeon Chub* & 2 & 1 \\
Sand Shiner & 97 & 224 \\
River Carpsucker & 0 & 3 \\
Plains Minnow & 5 & 1 \\
Western Silvery Minnow & 6 & 1 \\
\% Community Similarity & & $\mathbf{5 0 . 6}$ \\
\hline Taxa Similarity & & $\mathbf{7 7 . 8}$ \\
\hline
\end{tabular}

spawning (e.g. male spawning colors, pregnant females) during the June sampling date, but not in July. Since this site (Site 5) had extensive gravel runs, it was likely being used by most litho-obligate reproductive species in the vicinity. Sand shiners have become the dominant minnow species in the July sample, and it seems as though this is occurring at other mainstem sites in the watershed. The dominant community indicator species by percentage across all sites were the sand shiner $(61 \%)$, flathead chub (28\%), and longnose dace $(5 \%)$, followed by the channel catfish ( $2 \%)$, plains minnow $(2 \%)$, goldeneye $(1 \%)$, and western silvery minnow (1\%). 


\section{IBI vs. $O / E$}

For the Middle Powder River assessment of fish communities, the Fish IBI (Bramblett 2005) was inadequate to determine the fish community integrity, although it did correlate strongly with the habitat quality index $(\mathrm{r}=0.74, \mathrm{p}<0.05)$. IBI values continually ranked the sites as having fair biological integrity. On two sites with long stretches of monotonous sandy-glide habitat, we failed to capture 100 fish individuals which may have affected the fish community metrics. Since this IBI assesses biotic integrity relative only to conditions as they currently exist; we can not go back pre-settlement and do an IBI assessment during those conditions. But by using the expected fish community given that the Powder River is a reference large prairie river, we can derive the fish species list of the best possible conditions given minimal anthropogenic stressors. The best expected overall fish community in the upper reaches consisted of 7.5 native species.

Figure 3. Fish IBI and O/E comparisons at the Powder River sites. Sites 5t1 \& 5t2 are June and July samples at Site 5, respectively.

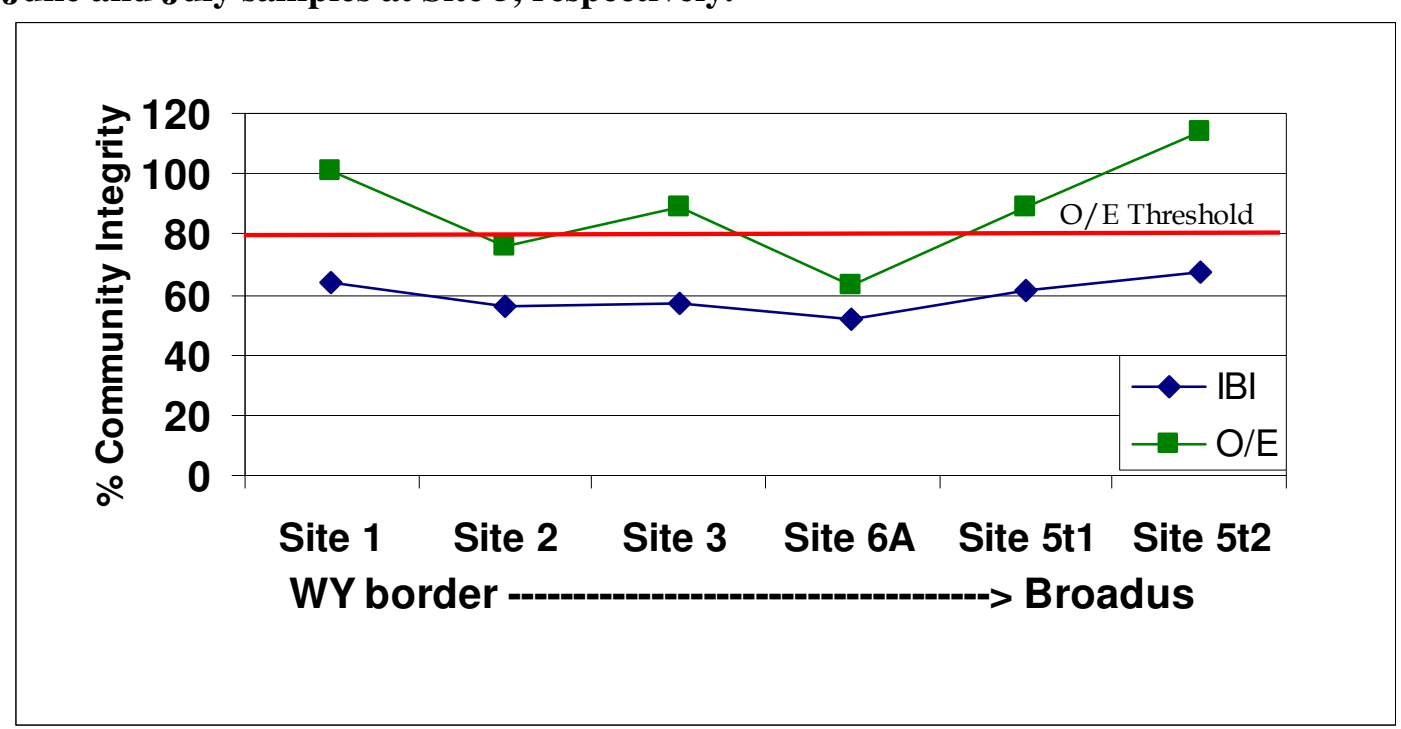

Even when Powder River sites had their full fish community present (Site 5), they still ranked low (fair) in biointegrity using the IBI (Figure 3). This can be explained in part, because the lowest scoring metrics were those with adjustments for catchment area, such as number of native species and number of native families. The Powder River is a diverse system, but not considering the fish community that has evolved within this unique system, and just assuming a linear increase in fish species to watershed area is not a valid assumption. This factor brings into question the suitability of this index to a watershed of this size. The largest catchment area of sites used by Bramblett et al. (2005) in developing the fish IBI was less than $14,000 \mathrm{~km}^{2}$ while catchment areas for our sites on the Powder River ranged from $\sim 20,000 \mathrm{~km}^{2}$ to well over 23,000 $\mathrm{km}^{2}$.

\section{Historical Perspectives}

To truly evaluate the fisheries potential of the Powder River, a historical and riverwide data compilation was conducted to determine: what a native Montana Powder River fish community looked like? The Montana section of the river from the Wyoming border to the confluence with 
the Yellowstone River is highlighted in this study, although a report from Confluence Consulting (Endicott 2004) for WY, supplies us with additional main-stem sites to review. These data were compiled from the MT Fish Wildlife \& Parks MFISH database of fish collections reported in the Powder River over the past 30 years, including the MTNHP and USGS collections in 2005 from sites in the Middle Powder sub-watershed from the WY border to Broadus.

The initial results are surprising. Using sites from 1975, 19 species of fish (17 natives) were present in the Montana's Powder River, while a cumulative look at samples since then show 18 fish species (15 native) (Table 7). Lake Chubs (Couesius plumbeus) that were reported by Bruce Rehwinkel (BR) from 4 of 7 sites in 1975 and 1976 seem to have disappeared from the entire Powder River System. Two species also reported in 1975 that have not been reported since are the brassy minnow and the green sunfish; both species were represented by 1 individual at the Locate, MT site. Given the ecological requirements of these species, they are presumably "wash-ins" from Mizpah Creek which joins the Powder River $\sim 5 \mathrm{~km}$ upstream of this sampling site. Mizpah Creek provides more suitable habitat for these smaller stream species. The creek chub was reported once ( 2 individuals) in 1975, and has not been reported in Montana's mainstem Powder since, but Confluence (2004) reported one creek chub collected $\sim 15$ miles from Montana at river mile 235.

If we examine just one of the shared collection sites (Wyoming border site1) at river mile 219, thirty years later (Table 6), we notice that the Percent Community Similarity is very low at $24 \%$, but more surprisingly, the taxa similarity is only 58\%. Five of the 12 species were not shared between the samples, and 2 common taxa collected in 1975, lake and sturgeon chubs were absent from the 2005 samples, and in fact sturgeon chubs have not been collected within 30 miles of this site in the past 5 years. We see a shift from a flathead chub dominated community to a dominance of sand shiners. This pattern may have to be further investigated to see if sand shiners are in fact more tolerant and their increasing numbers represents declining water quality. The one bright point of this site review is that there were no carp collected during 2005 sample.

Table 6. Powder River fish samples @ the Wyoming border taken 30 years apart.

\begin{tabular}{lrr}
\hline Taxa & 15-Oct-75 & 11-Jul-05 \\
\hline Channel Catfish & 1 & 3 \\
Common Carp & 4 & 0 \\
Goldeye & 10 & 3 \\
Longnose Dace & 3 & 3 \\
Flathead Chub & 965 & 96 \\
Lake Chub* & 33 & 0 \\
Sturgeon Chub* & 25 & 0 \\
Sand Shiner & 5 & 305 \\
River Carpsucker & 3 & 1 \\
Shorthead Redhorse & 7 & 1 \\
Sauger* & 1 & 0 \\
Plains Minnow & 0 & 12 \\
O/E & $\mathbf{1 . 2 7}$ & $\mathbf{1 . 0 7}$ \\
Percent Community Similarity & & $\mathbf{2 4 . 6 \%}$ \\
\hline Taxa Similarity & & $\mathbf{5 8 . 3 \%}$ \\
\hline
\end{tabular}


Table 7. Cumulative species list and percentage of site occurrences of fish collected on the mainstem Powder River in Montana (0-220 river miles). Asterisk (*) indicates fish species that have not been collected since the 1970's collections

\begin{tabular}{lcc}
\hline & $\begin{array}{c}1975 \\
(\mathrm{n}=7)\end{array}$ & $\begin{array}{c}2005 \\
(\mathrm{n}=28)\end{array}$ \\
\hline Brassy Minnow* & 14.3 & 0.0 \\
Burbot & 28.6 & 12.0 \\
Channel Catfish & 100.0 & 96.0 \\
Common Carp & 28.6 & 24.0 \\
Creek Chub* & 14.3 & 0.0 \\
Flathead Chub & 100.0 & 96.0 \\
Goldeye & 57.1 & 64.0 \\
Green Sunfish* & 28.6 & 0.0 \\
Lake Chub* & 57.1 & 0.0 \\
Longnose Dace & 71.4 & 48.0 \\
Longnose Sucker & 0.0 & 8.0 \\
Plains Minnow & 42.9 & 44.0 \\
Plains Killifish & 0.0 & 8.0 \\
River Carpsucker & 57.1 & 56.0 \\
Sand Shiner & 14.3 & 40.0 \\
Sauger & 28.6 & 40.0 \\
Shorthead Redhorse & 28.6 & 48.0 \\
Shovelnose Sturgeon & 14.0 & 24.0 \\
Stonecat & 14.3 & 12.0 \\
Sturgeon Chub & 100.0 & 48.0 \\
Walleye & 0.0 & 20.0 \\
Western Silvery Minnow & 71.4 & 60.0 \\
\hline Total Species & $\mathbf{1 9}$ & $\mathbf{1 8}$ \\
Total Native Species & $\mathbf{1 7}$ & $\mathbf{1 5}$ \\
\hline
\end{tabular}

Sturgeon chubs, MT SOC and former ESA candidate species, had a percent occurrence in BR's samples of $100 \%$ and averaged $5 \%$ of the species community. In the past 5 years, the sturgeon chub has been collected at less than $50 \%$ of the main-stem Powder River sites sampled and is usually represented by only 1 or 2 individuals per sample ( $<1 \%$ of the community). The rarity of sturgeon chub is alarming for a river that presumably provides the most substantial habitat for this declining species. Walleye were not found in BR samples and today occur in about $20 \%$ of sites sampled. Plains killifish, an introduced fish, has also appeared in the Powder River samples more recently, usually representing a couple of individuals, but any noticeable increases in the numbers of this species could be indicative of decreasing water quality. The plains killifish is tolerant of high salinities and alkalinities and is able to withstand extremes in these water chemical parameters long after other fish are gone (Baxter and Stone 1995). Sand shiners are being collected more frequently now (40\% vs.14\% of sites) and comprise a much higher percentage of the fish community that they did in the 1970's. 


\section{Macroinvertebrate Community Analysis}

Macroinvertebrate taxa lists and abundances are presented for each sample in Appendix B.

Overall, 59 taxa were reported from all sites with indicator species from 3 species assemblages (Appendix E). Average macroinvertebrate taxa richness per site is 23.4 taxa. The Species of Special Concern (SOC) mayfly: Raptoheptagenia cruentata (G4, S2) was found at all sampled sites, being more abundant in the targeted-riffle samples. The other rare mayflies: Anepeorus rusticus $(\mathrm{G} 1, \mathrm{~S} 1)$ and Homoeoneuria alleni $(\mathrm{G} 4, \mathrm{~S} 2)$ were only found at the Dry Creek site 2 in the Reach-Wide sample, represented by 2 individuals each, respectively. There was no significant difference in the number of taxa sampled in the targeted riffle (TR) vs. reach-wide (RW) EMAP samples ( $\mathrm{F}$ test, $\mathrm{p}=0.68$ ). The number of individuals obtained in a sample was significantly higher in the TR vs. RW EMAP samples ( $F$ test, $p<0.0001$ ). Two TR samples had to be sub-sampled to reduce the number of organisms to obtain the targeted 500 count. Targetedriffle samples across all sites were more similar to each other than they were to the same site reach-wide EMAP samples (Figure 4). In fact, samples using the reach wide protocols produced 2 distinct community clusters (Figure 4, species groups $2 \& 4$ ), representing the different macrohabitats being sampled.

Figure 4. Cluster analysis of relativized macroinvertebrate abundance data taken with two EMAP protocols.

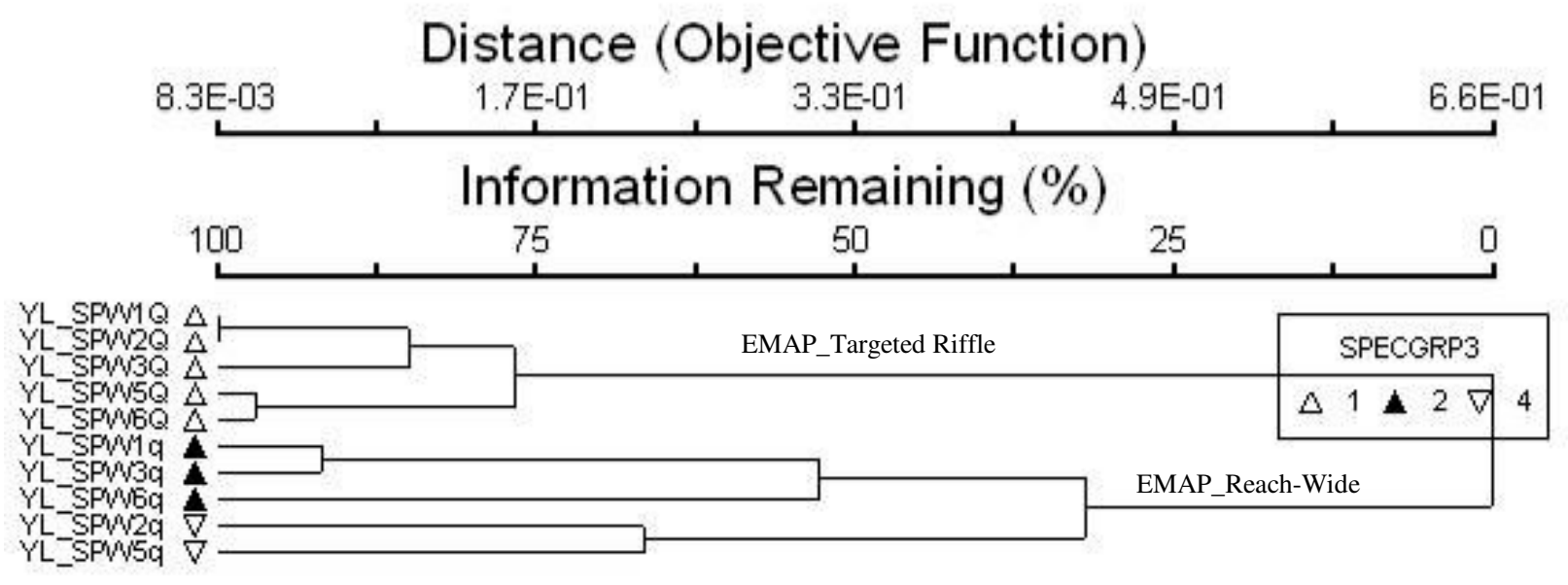

Despite clear separation of the 2 EMAP methods in a cluster analysis (PC-ORD, relatived abundance), the Montana multi-metric scores (MMI) did not significantly vary and the sites were all classified in the non-impaired category (Table 8). Even though all sites ranked unimpaired, there is a 20 point scoring spread from the lowest MMI score 45.5 (Site $2 \mathrm{RW}$ ) to 65.4 (Site 5 $\mathrm{RW}$ ). Thus site 5 (RW and TR) and site 3 targeted-riffle scores seem to represent sites with the highest macroinvertebrate community integrity (Table 8 ). Although, the metrics chosen for this plains MMI do not seem to represent the unique invertebrate community of the Powder River very well, as indicated by 2 of the metrics: $\%$ Tanypodinae \& \% Orthocladiinae of Chironomidae having no representative scores in 8 of the 10 samples evaluated (Appendix C). An evaluation of other metrics for the Powder River should be investigated to obtain more robust community measures, or further develop an invertebrate $\mathrm{O} / \mathrm{E}$, as we did with the fish communities in the Powder Watershed. 
Table 8. Overall macroinvertebrate results, sample date, percent sub-sampled, total taxa richness, number of individuals in the sample, multimetric index score, and aquatic impairment status for each stream site.

\begin{tabular}{|l|c|l|c|c|c|c|c|l|}
\hline Site & site_code & Method & Date & $\begin{array}{c}\text { \% Sample } \\
\text { Used }\end{array}$ & T_Taxa & \#Ind & MMI & Status \\
\hline Powder River 1 & YL_SPW1Q & $\begin{array}{l}\text { EMAP_Targeted } \\
\text { Riffle (8 comp) }\end{array}$ & $07 / 11 / 2005$ & 66.67 & 26 & 597 & 57.0 & $\begin{array}{l}\text { Non- } \\
\text { Impaired }\end{array}$ \\
\hline Powder River 1 & YL_SPW1q & EMAP_Reach-wide & $07 / 11 / 2005$ & 100 & 28 & 296 & 58.1 & $\begin{array}{l}\text { Non- } \\
\text { Impaired }\end{array}$ \\
\hline Powder River 2 & YL_SPW2Q & $\begin{array}{l}\text { EMAP_Targeted } \\
\text { Riffle (8 comp) }\end{array}$ & $07 / 11 / 2005$ & 50 & 26 & 613 & 52.3 & $\begin{array}{l}\text { Non- } \\
\text { Impaired }\end{array}$ \\
\hline Powder River 2 & YL_SPW2q & EMAP_Reach-wide & $07 / 11 / 2005$ & 100 & 25 & 257 & 45.5 & $\begin{array}{l}\text { Non- } \\
\text { Impaired }\end{array}$ \\
\hline Powder River 3 & YL_SPW3Q & $\begin{array}{l}\text { EMAP_Targeted } \\
\text { Riffle (8 comp) }\end{array}$ & $07 / 11 / 2005$ & 100 & 25 & 235 & 60.2 & $\begin{array}{l}\text { Non- } \\
\text { Impaired }\end{array}$ \\
\hline Powder River 3 & YL_SPW3q & EMAP_Reach-wide & $07 / 11 / 2005$ & 100 & 19 & 234 & 46.4 & $\begin{array}{l}\text { Non- } \\
\text { Impaired }\end{array}$ \\
\hline Powder River 6 & YL_SPW6Q & $\begin{array}{l}\text { EMAP_Targeted } \\
\text { Riffle (8 comp) }\end{array}$ & $07 / 12 / 2005$ & 100 & 19 & 224 & 49.0 & $\begin{array}{l}\text { Non- } \\
\text { Impaired }\end{array}$ \\
\hline Powder River 6 & YL_SPW6q & EMAP_Reach-wide & $07 / 12 / 2005$ & 100 & 23 & 265 & 57.3 & $\begin{array}{l}\text { Non- } \\
\text { Impaired }\end{array}$ \\
\hline Powder River 5 & YL_SPW5Q & $\begin{array}{l}\text { EMAP_Targeted } \\
\text { Riffle (8 comp) }\end{array}$ & $07 / 12 / 2005$ & 100 & 23 & 426 & 60.5 & $\begin{array}{l}\text { Non- } \\
\text { Impaired }\end{array}$ \\
\hline Powder River 5 & YL_SPW5q & EMAP_Reach-wide & $07 / 12 / 2005$ & 100 & 20 & 261 & 65.4 & $\begin{array}{l}\text { Non- } \\
\text { Impaired }\end{array}$ \\
\hline
\end{tabular}

Figure 5. Relationship between the habitat scores, Fish $\mathrm{O} / \mathrm{E}$ and the macroinvertebrate MMI index scores. Impairment thresholds are lines @ $0.8(\mathrm{O} / \mathrm{E})$ and $37(\mathrm{MMI})$.

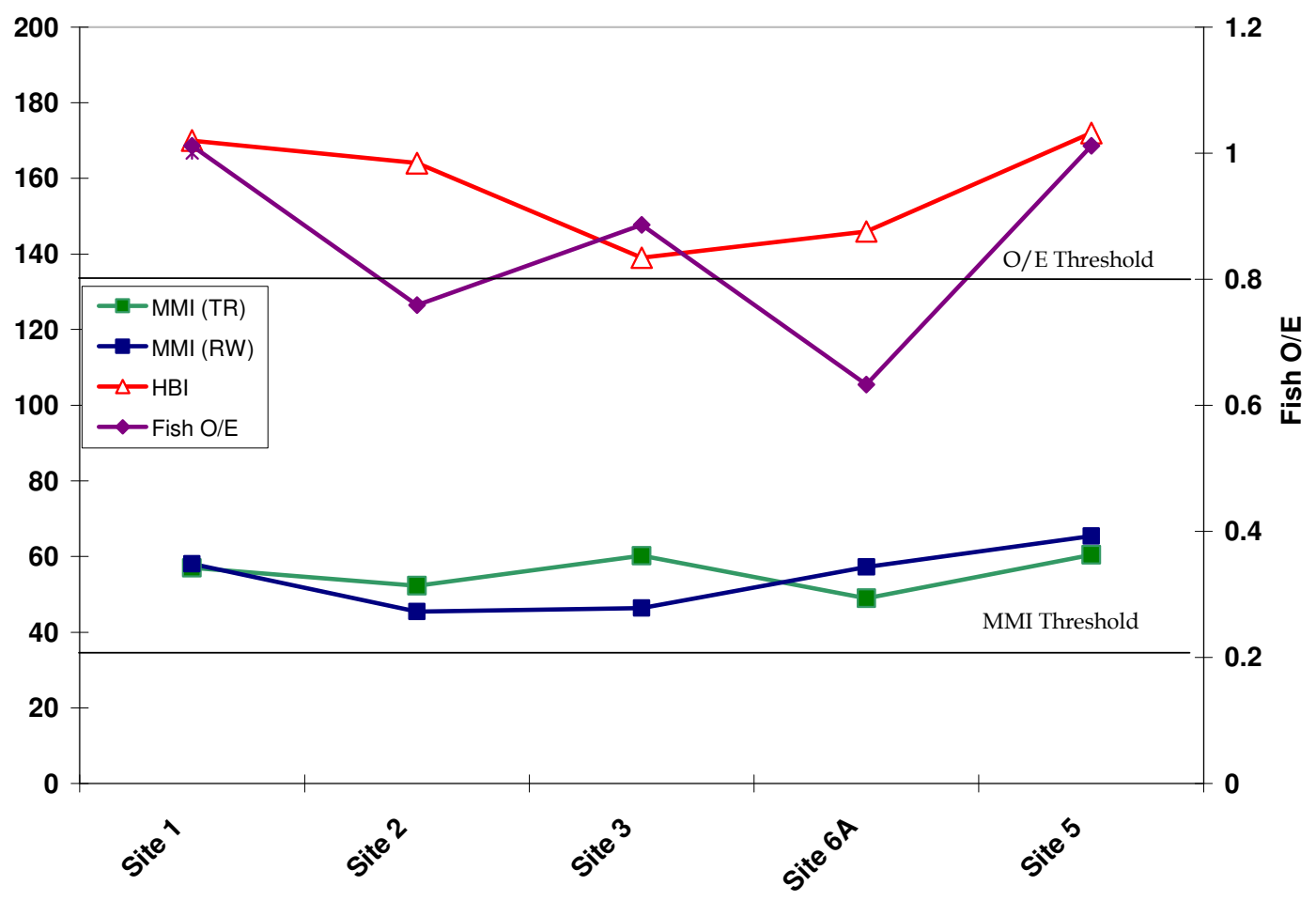


EMAP Targeted Riffle samples correlated with the fish O/E scores more closely than the reachwide samples (TR x O/E, $r=0.87 \mathrm{p}<0.01$ vs. RW x O/E, $\mathrm{r}=0.41 \mathrm{p}>0.05$ ) (Figure 5).

The Bloom Creek site reported 22 macroinvertebrate taxa and was dominated by highly tolerant organisms with a MT biotic index of 8.21 and an old DEQ metric score of 11 of 24 (Bukantis 1998) which indicates moderate impairment. This site was highly impacted by cattle intrusions into the stream channel and riparian zone, as indicated by low HQI scores (BLM-12 / EPA-137).

\section{CONCLUSIONS \& RECOMMENDATIONS}

1. All sites of the mainstem Powder River within the Middle Powder ranked unimpaired with the MMI, but by incorporating the fish $\mathrm{O} / \mathrm{E}$ and habitat scores, a clearer designation of biological integrity can be made. Fish O/E analysis ranked site 6 as impaired and Site 2 as borderline impaired, but taking all data into account, including the presence of 3 of 5 SOC mayflies, Site 2 could be moved into the unimpaired category using Best Professional Judgement. Community Integrity results from the fish, habitat and macroinvertebrate surveys combined to rank the Powder River reach upstream of Rough Creek (Site 5) the most biologically intact, followed by the Powder River reach @ the Wyoming border (Site 1) and finally Site (2), the Dry Creek reach. We recommend choosing these as integrator and future monitoring sites.

2. Results for macroinvertebrate samples show that the EMAP Targeted Riffle samples produce more bugs, track the fish O/E closer, evaluate more consistently across sites and are an easily repeatable protocol for less variability in field operations. Therefore, we recommend the EMAP Targeted-Riffle Protocols for future monitoring efforts.

3. Sturgeon chubs are obviously declining. Patton et al. (1998) found sturgeon chubs at half of the eight sites sampled in the Wyoming portions of the Powder River, Confluence Consulting (2004) found sturgeon chubs (2) in 2002 at only 1 WY site close to the MT border, MTNHP and the USGS (2005) did not capture a single sturgeon chub within 40 miles of the WY border despite sampling 6 reaches. The rarity of the sturgeon chub is alarming for a river that is supposed to provide the most substantial habitat for this species. We recommend additional work on the distributional status and tolerance to water chemistry changes of the sturgeon chub and the SOC mayflies as a component of any biomonitoring approach for CBM development in the immediate Powder River basin. 


\section{Literature Cited}

Allan, J. D., D. L. Erickson and J. Fay. 1997. The influence of catchment land use on stream integrity across multiple spatial scales. Freshwater Biology 37:149-162.

Barbour, M., J. Gerritsen, B.D. Snyder, and J.B. Stribling. 1999. Rapid Bioassessment Protocols for Use in Streams and Wadable Rivers: Periphyton, Benthic Macroinvertebrates and Fish,Second Edition. EPA 841-B-99-002. United States Environmental Protection Agency; Office of Water: Washington, D.C..

Backes, K.M. et al. 1994. Lower Yellowstone River Pallid Sturgeon Study. Montana Dept. of Fish, Wildlife and Parks \& Bureau of Reclamation. 19pp.

Baxter, G.T. and M.D. Stone. 1995. Fishes of Wyoming. Wyoming Game and Fish Department

Bramblett, R. G., T. R. Johnson, A. V. Zale, A. V., and D. Heggem. 2005. Development and Evaluation of a Fish Assemblage Index of Biotic Integrity for Northwestern Great Plains Transactions of the American Fisheries Society 134:624-640, 2005.

Bukantis, R. 1998. Rapid bioassessment macroinvertebrate protocols: Standard Operating Procedures. Montana Department of Environmental Quality, Helena, Montana.

Confluence Consulting. 2004. Powder River Biological Survey and Implications for Coalbed Methane Development prepared for Powder River Basin Resource Council. 67 pp. + appendicies.

Davis, W. and B. Bramblett. 2006. Effects of Coalbed Natural Gas Development on Fish Assemblages in the Powder River Basin. Montana Cooperative Fishery Research Unit Fact Sheet, Montana State Univeristy. 3pp.

Dodds, W. K., K. Gido, M. R. Whiles, K. M. Fritz, and W. J. Matthews. 2004. Life on the edge: The ecology of Great Plains prairie streams. BioScience 54: 205-216.

Feldman, D. 2006. Interpretation of New Macroinvertebrate Models by WQPB. Draft Report. Montana Department of Environmental Quality, Planning Prevention and Assistance Division, Water Quality Planning Bureau, Water Quality Standards Section. 1520 E. $6^{\text {th }}$ Avenue, Helena, MT 59620. 14 pp.

Gustafson, D. Entomologist, Montana State University, Bozeman, MT. Personal communication. Jan 2006.

Holton, G. D., and H. E. Johnson. 2003. A field guide to Montana fishes, 3rd edition. Montana Fish, Wildlife, and Parks, Helena. 
Hubert, W.A. 1993. The Powder River: a relatively pristine stream on the Great Plains. In: Restoration Planning for Rivers of the Mississippi Ecosystem. US National Biological Survey Biological Report 19

Jessup, B., J. Stribling, and C. Hawkins. 2005. Biological indicators of stream condition in Montana using macroinvertebrates. Tetra Tech, Inc. November 2005 (draft).

Lazorchak, J.M., Klemm, D.J., and D.V. Peck (editors). 1998. Environmental Monitoring and Assessment Program - Surface Waters: Field Operations and Methods for Measuring the Ecological Condition of Wadeable Streams. EPA/620/R-94/004F. U.S. Environmental Protection Agency, Washington, D.C.

Patton, T.M, F.J. Rahel, and W.A. Hubert. 1998. Using historical data to assess changes in Wyoming's fish fauna. Conservation Biology 12:1120-1128.

Pflieger, W. L. 1997. The fishes of Missouri, revised edition. Missouri Department of Conservation, Jefferson City.

Rehwinkel, B.J. 1978. Powder River aquatic ecology report. Report prepared for Utah International, Inc. Montana Department of Fish and Game.

Riggs, V. and B. Gardner. 2000-2004. MFISH (Montana Fisheries Information System) survey reports. Accessed Jan 2006.

Scott, W. B., and E. J. Crossman. 1973. Freshwater fishes of Canada. Fisheries Research Board of Canada, Bulletin 184, Ottawa.

Stagliano, David, M. 2005. Aquatic Community Classification and Ecosystem Diversity in Montana's Missouri River Watershed. Report to the Bureau of Land Management. Montana Natural Heritage Program, Helena, Montana. 65 pp. plus appendices.

Werdon, S.J. 1992. Population status and characteristics of Macrhybopsis Gelida, Platygobio Gracilis and Rhinichthys Cataractae in the Missouri River Basin. South Dakota State University, Brookings, SD. M.S. Thesis, 55pp. 
Appendix A. Raw data and IBI metric calculation from fish data collected from Middle Powder Watershed

\begin{tabular}{|c|c|c|c|c|c|c|c|c|c|c|c|c|}
\hline & Site 1 & & Site 2 & & Site 3 & & Site 4 & & Site 5 & & Site $5 \mathrm{t} 1$ & \\
\hline Channel Catfish & 3.0 & & 4.0 & & 1.0 & & 0.0 & & 2.0 & & 11.0 & \\
\hline Common Carp & 0.0 & & 2.0 & & 0.0 & & 0.0 & & 0.0 & & 0.0 & \\
\hline Flathead Chub & 96.0 & & 47.0 & & 30.0 & & 26.0 & & 46.0 & & 116.0 & \\
\hline Goldeye & 3.0 & & 0.0 & & 2.0 & & 0.0 & & 3.0 & & 0.0 & \\
\hline Longnose Dace & 3.0 & & 2.0 & & 3.0 & & 0.0 & & 1.0 & & 62.0 & \\
\hline Plains Minnow & 12.0 & & 0.0 & & 3.0 & & 1.0 & & 1.0 & & 5.0 & \\
\hline Plains Killifish & 0.0 & & 0.0 & & 0.0 & & 2.0 & & 0.0 & & 0.0 & \\
\hline River Carpsucker & 1.0 & & 0.0 & & 0.0 & & 1.0 & & 3.0 & & 0.0 & \\
\hline Sand Shiner & 305.0 & & 97.0 & & 19.0 & & 47.0 & & 224.0 & & 97.0 & \\
\hline Shorthead Redhorse & 1.0 & & 0.0 & & 0.0 & & 0.0 & & 0.0 & & 0.0 & \\
\hline Stonecat & 0.0 & & 2.0 & & 0.0 & & 0.0 & & 0.0 & & 0.0 & \\
\hline Sturgeon Chub* & 0.0 & & 0.0 & & 0.0 & & 0.0 & & 1.0 & & 2.0 & \\
\hline Western Silvery Minnow & 0.0 & & 2.0 & & 2.0 & & 1.0 & & 1.0 & & 6.0 & \\
\hline Total \# species & 8.0 & & 7.0 & & 7.0 & & 6.0 & & 9.0 & & 7.0 & \\
\hline Native Species & 8.0 & & 6.0 & & 7.0 & & 5.0 & & 9.0 & & 7.0 & \\
\hline Total Individuals & 424.0 & & 156.0 & & 60.0 & & 78.0 & & 282.0 & & 299.0 & \\
\hline \# Minnow Species Thrive & 4.0 & & 4.0 & & 5.0 & & 4.0 & & 6.0 & & 6.0 & \\
\hline Proportion of tolerant individuals & 0.00 & & 0.01 & & 0.00 & & 0.03 & & 0.00 & & 0.00 & \\
\hline \# Sucker + Catfish Species & 3.0 & & 2.0 & & 1.0 & & 1.0 & & 2.0 & & 2.0 & \\
\hline$\%$ Insectivorous Minnows & 0.2 & & 0.3 & & 0.6 & & 0.3 & & 0.2 & & 0.6 & \\
\hline \# Benthic Invertivore Species & 4.0 & & 3.0 & & 2.0 & & 2.0 & & 4.0 & & 3.0 & \\
\hline \% Litholphilic Spawners & 0.7 & & 0.6 & & 0.4 & & 0.6 & & 0.8 & & 0.5 & \\
\hline \% Parental Care & 0.01 & & 0.03 & & 0.02 & & 0.00 & & 0.01 & & 0.04 & \\
\hline$\%$ Native to Montana & 100.0 & & 98.7 & & 100.0 & & 97.4 & & 100.0 & & 100.0 & \\
\hline \multirow[t]{2}{*}{ \# Long Lived Species } & 4.0 & & 3.0 & & 4.0 & & 3.0 & & 6.0 & & 5.0 & \\
\hline & Site 1 & & Site 2 & & Site 3 & & Site 4 & & Site 5 t2 & & Site $5 \mathrm{t} 1$ & \\
\hline & Adjust & & Adjust & & Adjust & & Adjust & & Adjust & & Adjust & \\
\hline Metrics & Value & Score & Value & Score & Value & Score & Value & Score & Value & Score & Value & Score \\
\hline Number of Native Fish Species to Montana & 6.9 & 38.1 & 4.9 & 27.0 & 5.9 & 32.6 & 3.9 & 21.5 & 7.9 & 43.7 & 5.9 & 32.6 \\
\hline Number of Native Fish Families to Montana & 3.8 & 70.6 & 1.8 & 33.7 & 2.8 & 52.1 & 1.8 & 33.7 & 3.8 & 70.6 & 1.8 & 33.7 \\
\hline Proportion of tolerant individuals & 8.0 & 91.5 & 1.0 & 98.9 & 0.0 & 100.0 & 3.0 & 96.8 & 0.0 & 100.0 & 0.0 & 100.0 \\
\hline Number of Sucker and Catfish Species & 2.4 & 26.4 & 1.4 & 15.5 & 0.4 & 4.6 & 0.4 & 4.6 & 1.4 & 15.5 & 1.4 & 15.5 \\
\hline $\begin{array}{l}\text { Proportion out of the Total Number of Fish That } \\
\text { Were Insect eating Minnows }\end{array}$ & 24.0 & 33.0 & 31.0 & 42.6 & 58.0 & 79.7 & 33.0 & 45.3 & 18.0 & 24.7 & 60.0 & 82.4 \\
\hline $\begin{array}{l}\text { Total Number of Species That Prefer to Eat } \\
\text { Insects That Live on the Stream Bottom }\end{array}$ & 3.6 & 60.5 & 2.6 & 43.5 & 1.6 & 26.5 & 1.6 & 26.5 & 3.6 & 60.5 & 2.6 & 43.5 \\
\hline $\begin{array}{l}\text { Proportion of the Total Number of Fish That } \\
\text { Require Rocks to Lay Eggs }\end{array}$ & 73.0 & 88.0 & 65.0 & 78.4 & 37.0 & 44.6 & 62.0 & 74.8 & 81.0 & 97.7 & 54.0 & 65.1 \\
\hline $\begin{array}{l}\text { Proportion of the Total Number of Individuals } \\
\text { That Do Not Require Rocks, But Have Parental } \\
\text { Care of Eggs }\end{array}$ & 1.0 & 98.9 & 3.0 & 96.6 & 2.0 & 97.7 & 0.0 & 100.0 & 1.0 & 98.9 & 4.0 & 95.5 \\
\hline $\begin{array}{l}\text { Proportion of the Total Number of Fish Sampled } \\
\text { That Were Native to Montana }\end{array}$ & 100.0 & 100.0 & 98.7 & 98.7 & 100.0 & 100.0 & 97.0 & 97.0 & 100.0 & 100.0 & 100.0 & 100.0 \\
\hline Number of Long-Lived Native Species & 3.3 & 33.9 & 2.3 & 23.7 & 3.3 & 33.9 & 2.3 & 23.7 & 5.3 & 54.4 & 4.3 & 44.2 \\
\hline IBI Score & & $\begin{array}{c}640.9 \\
64\end{array}$ & & $\begin{array}{c}558.6 \\
56\end{array}$ & & $\begin{array}{c}571.8 \\
\mathbf{5 7}\end{array}$ & & $\begin{array}{c}523.9 \\
52\end{array}$ & & $\begin{array}{c}665.9 \\
67\end{array}$ & & $\begin{array}{c}612.4 \\
61\end{array}$ \\
\hline
\end{tabular}


Appendix B. Frequencies of fish species occurrence ( $\mathrm{F}$ of $\mathrm{O}$ ) across different segments of the Powder River. All sites includes 2 Wyoming sites @ river mile 225 and 235, all MT sites includes sites from river mile 220 downstream to the confluence with the Yellowstone.

\begin{tabular}{|c|c|c|c|c|c|}
\hline & $\mathrm{F}$ of $\mathrm{O}$ & $\mathrm{F}$ of $\mathrm{O}$ & $\mathrm{F}$ of $\mathrm{O}$ & $\mathrm{F}$ of $\mathrm{O}$ & $\mathrm{F}$ of $\mathrm{O}$ \\
\hline & $\begin{array}{l}\text { All Sites } \\
(n=30)\end{array}$ & $\begin{array}{l}\text { All MT } \\
\text { Sites } \\
(n=28)\end{array}$ & $\begin{array}{c}\text { Lower } \\
\text { 20rm } \\
(\mathrm{n}=10)\end{array}$ & $\begin{array}{l}\text { All Sites } \\
>20 \mathrm{rm} \\
(\mathrm{n}=18)\end{array}$ & $\begin{array}{c}1975 \text { BR } \\
\text { sites } \\
(n=7)\end{array}$ \\
\hline Brassy Minnow $^{1}$ & 0.03 & 0.04 & 0.00 & 0.06 & 0.14 \\
\hline Burbot & 0.10 & 0.11 & 0.13 & 0.06 & 0.29 \\
\hline Channel Catfish & 0.93 & 0.96 & 1.00 & 0.94 & 1.00 \\
\hline Common Carp ${ }^{1}$ & 0.20 & 0.21 & 0.38 & 0.17 & 0.29 \\
\hline Creek Chub & 0.07 & 0.07 & 0.00 & 0.06 & 0.14 \\
\hline Flathead Chub & 0.97 & 0.96 & 0.88 & 1.00 & 1.00 \\
\hline Goldeye & 0.60 & 0.61 & 1.00 & 0.44 & 0.57 \\
\hline Green Sunfish ${ }^{1}$ & 0.07 & 0.07 & 0.00 & 0.11 & 0.29 \\
\hline Lake Chub & 0.13 & 0.14 & 0.00 & 0.22 & 0.57 \\
\hline Longnose Dace & 0.50 & 0.46 & 0.00 & 0.83 & 0.71 \\
\hline Longnose Sucker & 0.07 & 0.07 & 0.25 & 0.00 & 0.00 \\
\hline Plains Minnow & 0.47 & 0.50 & 0.00 & 0.67 & 0.43 \\
\hline Plains Killifish $^{1}$ & 0.17 & 0.14 & 0.00 & 0.28 & 0.00 \\
\hline River Carpsucker & 0.57 & 0.57 & 0.38 & 0.61 & 0.57 \\
\hline Sand Shiner & 0.50 & 0.46 & 0.00 & 0.67 & 0.14 \\
\hline Sauger & 0.33 & 0.36 & 1.00 & 0.06 & 0.29 \\
\hline Shorthead Redhorse & 0.40 & 0.43 & 0.88 & 0.32 & 0.29 \\
\hline Shovelnose Sturgeon & 0.20 & 0.21 & 0.75 & 0.00 & 0.00 \\
\hline Stonecat & 0.13 & 0.11 & 0.13 & 0.22 & 0.14 \\
\hline Sturgeon Chub* & 0.50 & 0.54 & 0.13 & 0.61 & 1.00 \\
\hline Walleye & 0.17 & 0.18 & 0.63 & 0.00 & 0.00 \\
\hline Western Silvery Minnow & 0.60 & 0.57 & 0.50 & 0.67 & 0.71 \\
\hline Total \# Expected Species & 7.70 & 7.79 & 8.00 & 7.53 & 8.57 \\
\hline Total \# species $>\mathbf{5 0 \%}$ & 7.00 & 7.00 & 8.00 & 8.00 & 8.00 \\
\hline
\end{tabular}

${ }^{1}$ Species not included in the sum for total expected species. 
Appendix C. Macroinvertebrate taxa lists, abundance and plains MMI table calculations on the last page for each Powder River site. 
Appendix C. Powder River, Site 1 @ Wyoming border. Targeted-Riffle EMAP

\begin{tabular}{|c|c|c|c|c|c|}
\hline Order & FinallD & Individuals & TolVal & FFG & Habit \\
\hline Coleoptera & Helichus & 2 & 5 & SC & "CN/75\%, CM/25\%" \\
\hline Coleoptera & Microcylloepus pusillus & 7 & 5 & CG & "CN/50\%, BU/50\%" \\
\hline Coleoptera & Stenelmis & 6 & 5 & SC/CG & "CN/50\%, BU/50\%" \\
\hline Diptera & Polypedilum & 7 & 6 & $\mathrm{SH}$ & $\mathrm{CN}$ \\
\hline Diptera & Hemerodromia & 5 & 6 & PR & SP \\
\hline Diptera & Cricotopus & 1 & 8 & $\mathrm{CG} / \mathrm{SH}$ & $\mathrm{CN}$ \\
\hline Diptera & Simulium & 78 & 5 & CF & $\mathrm{CN}$ \\
\hline Ephemeroptera & Traverella albertana & 234 & 2 & $\mathrm{CF}$ & $\mathrm{CN}$ \\
\hline Ephemeroptera & $\begin{array}{l}\text { Raptoheptagenia } \\
\text { cruentata }\end{array}$ & 8 & 2 & PR & $\mathrm{CN}$ \\
\hline Ephemeroptera & Acentrella turbida & 1 & 4 & CG & "SW/10\%, CN/90\%" \\
\hline Ephemeroptera & Acerpenna & 2 & 4 & SC & "SW/10\%, CN/90\%" \\
\hline Ephemeroptera & Cercobrachys & 3 & 6 & CG & "SP/75\%, CM/90\%" \\
\hline Ephemeroptera & Fallceon quilleri & 22 & 5 & CG & "SW/10\%, CN/90\%" \\
\hline Ephemeroptera & Hexagenia limbata & 5 & 6 & $\mathrm{CG}$ & $\mathrm{BU}$ \\
\hline Ephemeroptera & Isonychia & 15 & 2 & CF & $\mathrm{SW} / \mathrm{CN}$ \\
\hline Ephemeroptera & Leucrocuta & 8 & 1 & SC & $\mathrm{CN}$ \\
\hline Ephemeroptera & Tricorythodes & 44 & 4 & CG & $\mathrm{CN} / \mathrm{SP}$ \\
\hline Haplotaxida & Tubificidae & 2 & 10 & CG & $\mathrm{BU}$ \\
\hline Hemiptera & Ambrysus mormon & 5 & 3 & PR & unk \\
\hline $\begin{array}{l}\text { Odonata } \\
\text { Odonata }\end{array}$ & $\begin{array}{l}\text { Ophiogomphus severus } \\
\text { Stylurus intricatus }\end{array}$ & $\begin{array}{l}2 \\
1\end{array}$ & 5 & $\begin{array}{l}\text { PR } \\
\text { PR }\end{array}$ & $\begin{array}{l}\text { unk } \\
\text { unk }\end{array}$ \\
\hline Plecoptera & Acroneuria abnormis & 2 & 2 & PR & $\mathrm{CN}$ \\
\hline Trichoptera & Hydropsyche confusa & 4 & & unk & $\mathrm{CN}$ \\
\hline Trichoptera & $\begin{array}{l}\text { Brachycentrus } \\
\text { occidentalis }\end{array}$ & 6 & 2 & $\mathrm{CF}$ & $\mathrm{CN}$ \\
\hline Trichoptera & Cheumatopsyche & 124 & 5 & CF & $\mathrm{CN}$ \\
\hline Trichoptera & Hydropsyche morosa gr. & 3 & 6 & unk & $\mathrm{CN}$ \\
\hline
\end{tabular}




\section{Appendix C. (cont.) Powder River Site 1 @ Wyoming border. Reach-wide EMAP}

\begin{tabular}{|c|c|c|c|c|c|}
\hline Order & FinalID & Individuals & TolVal & FFG & Habit \\
\hline Coleoptera & Dubiraphia & 1 & 6 & SC/CG & "CN/50\%, BU/50\%" \\
\hline Coleoptera & Microcylloepus pusillus & 10 & 5 & CG & "CN/50\%, BU/50\%" \\
\hline Coleoptera & Stenelmis & 4 & 5 & $\mathrm{SC} / \mathrm{CG}$ & "CN/50\%, BU/50\%" \\
\hline Diptera & Potthastia gaedii Gr. & 1 & 3 & CG & SP \\
\hline Diptera & Polypedilum & 18 & 6 & $\mathrm{SH}$ & $\mathrm{CN}$ \\
\hline Diptera & Hemerodromia & 6 & 6 & PR & SP \\
\hline Diptera & Simulium & 5 & 5 & CF & $\mathrm{CN}$ \\
\hline Ephemeroptera & Raptoheptagenia cruentata & 13 & 2 & PR & $\mathrm{CN}$ \\
\hline Ephemeroptera & Traverella albertana & 19 & 2 & CF & $\mathrm{CN}$ \\
\hline Ephemeroptera & Acentrella insignificans & 1 & 4 & CG & "SW/10\%, CN/90\%" \\
\hline Ephemeroptera & Acerpenna & 2 & 4 & SC & "SW/10\%, CN/90\%" \\
\hline Ephemeroptera & Caenis latipennis & 1 & 7 & CG & "SP/75\%, CM/90\%" \\
\hline Ephemeroptera & Cercobrachys & 6 & 6 & CG & "SP/75\%, CM/90\%" \\
\hline Ephemeroptera & Fallceon quilleri & 3 & 5 & CG & "SW/10\%, CN/90\%" \\
\hline Ephemeroptera & Heptagenia & 6 & 4 & SC & $\mathrm{CN}$ \\
\hline Ephemeroptera & Hexagenia limbata & 3 & 6 & CG & $\mathrm{BU}$ \\
\hline Ephemeroptera & Leucrocuta & 4 & 1 & SC & $\mathrm{CN}$ \\
\hline Ephemeroptera & Tricorythodes & 38 & 4 & CG & CN/SP \\
\hline Haplotaxida & Lumbricina & 1 & 4 & CG & $\mathrm{BU}$ \\
\hline Hemiptera & Corixidae & 1 & 9 & $\mathrm{PH} / \mathrm{PR}$ & sW \\
\hline Hemiptera & Ambrysus mormon & 4 & 3 & PR & unk \\
\hline $\begin{array}{l}\text { Non-Insect } \\
\text { taxa }\end{array}$ & Nematoda & 2 & 5 & unk & BU \\
\hline Plecoptera & Acroneuria abnormis & 1 & 2 & PR & $\mathrm{CN}$ \\
\hline Trichoptera & Cheumatopsyche & 130 & 5 & CF & $\mathrm{CN}$ \\
\hline Trichoptera & Hydropsyche morosa gr. & 7 & 6 & unk & $\mathrm{CN}$ \\
\hline Trichoptera & Ithytrichia & 1 & 4 & SC & unk \\
\hline Trichoptera & Nectopsyche & 7 & 2 & $\mathrm{SH}$ & $\mathrm{CM} / \mathrm{SP} / \mathrm{CN}$ \\
\hline
\end{tabular}


Appendix C. (cont.) Powder River Site 2 @ Dry Creek. Targeted-Riffle EMAP

\section{Montana Bioassessment Report}

Waterbody Name: Powder River@drycreek

Benthic Sample ID: 14902

Station ID: YLBLMPW2T5

Reference

Site Classification:

Latitude:

Longitude:

Rep. Num: 0

STORET Activity ID: $\quad$ PW2T5-M

Collection Date: $\quad 07 / 11 / 2005$

Collection EMAP_T500

Total Number of Individuals in Sample:

\section{Sample Taxa List}

\begin{tabular}{|c|c|c|c|c|c|c|}
\hline Order: & OTU name: & FinalID: & ndividuals & Tol Val: & FFG: & Habit: \\
\hline Coleoptera & Helichus & Helıchus & $\begin{array}{l}1 \\
3\end{array}$ & $\begin{array}{l}5 \\
5\end{array}$ & $S C$ & $\begin{array}{l}\text { "CN//5\%, CM/25\%" } \\
\text { "CN/50\%, BU/ } / 50 \% "\end{array}$ \\
\hline Coleoptera & Stenelmis & Stenelmis & 2 & 5 & $S C / C G$ & "CN/50\%, BU/50\%" \\
\hline Diptera & Chironominae & Polypedilum & 5 & 6 & $\mathrm{SH}$ & $\mathrm{CN}$ \\
\hline Diptera & Hemerodromia & Hemerodromia & 5 & 6 & PR & SP \\
\hline Diptera & Orthocladiinae & Orthocladius & 1 & 7 & $\mathrm{CG}$ & SP/BU \\
\hline Diptera & Orthocladiinae & Parakiefferiella & 1 & 6 & CG & SP \\
\hline Diptera & Simuliidae & Simulium & 125 & 5 & $\mathrm{CF}$ & $\mathrm{CN}$ \\
\hline Ephemeropte & & Raptoheptagenia cruentata & 14 & 2 & PR & $\mathrm{CN}$ \\
\hline Ephemeropte & & Traverella albertana & 244 & 2 & $\mathrm{CF}$ & $\mathrm{CN}$ \\
\hline Ephemeropte & Acentrella & Acentrella turbida & 1 & 4 & CG & "SW/10\%, CN/90\%" \\
\hline Ephemeropte & Cercobrachys & Cercobrachys & 3 & & CG & "SP/75\%, CM/90\%" \\
\hline Ephemeropte & Fallceon & Fallceon quilleri & 12 & 5 & CG & "SW/10\%, CN/90\%" \\
\hline Ephemeropte & Hexagenia & Hexagenia limbata & 12 & 6 & $\mathrm{CG}$ & $\mathrm{BU}$ \\
\hline Ephemeropte & Isonychia & Isonychia & 8 & 2 & CF & SW/CN \\
\hline Ephemeropte & Leucrocuta & Leucrocuta & 4 & 1 & SC & $\mathrm{CN}$ \\
\hline Ephemeropte & Tricorythodes & Tricorythodes & 38 & 4 & CG & $\mathrm{CN} / \mathrm{SP}$ \\
\hline Haplotaxida & Oligochaeta & Tubificidae & 2 & 10 & CG & $\mathrm{BU}$ \\
\hline Hemiptera & Naucoridae & Ambrysus mormon & 2 & 3 & PR & unk \\
\hline Odonata & Gomphidae & Ophiogomphus severus & 3 & 5 & PR & unk \\
\hline Plecoptera & Acroneuria & Acroneuria abnormis & 2 & 2 & PR & $\mathrm{CN}$ \\
\hline Trichoptera & & Hydropsyche confusa & 1 & 6 & unk & $\mathrm{CN}$ \\
\hline Trichoptera & Brachycentrus & Brachycentrus occidentalis & 1 & 2 & $\mathrm{CF}$ & $\mathrm{CN}$ \\
\hline Trichoptera & Cheumatopsyche & Cheumatopsyche & 105 & 5 & $\mathrm{CF}$ & $\mathrm{CN}$ \\
\hline Trichoptera & Hydropsyche_Cer & Hydropsyche morosa gr. & 16 & 6 & unk & $\mathrm{CN}$ \\
\hline TRICHOPTE & Potamyia & POTAMYIA FLAVA & 2 & 4 & $\mathrm{CF}$ & \\
\hline
\end{tabular}


Appendix C. (cont.) Powder River Site 2 @ Dry Creek. Reach-Wide EMAP

\section{Montana Bioassessment Report}

Waterbody Name: Powder River@drycreek

Station ID: $\quad$ YLBLMPW205

Site Classification:

Collection Date: 07/11/2005

\section{Sample Taxa List}

Order: OTU name:

Coleoptera Dubiraphia

Diptera Chironominae

Diptera Chironominae

Diptera Chironominae

Diptera Hemerodromia

Diptera Orthocladiinae

Diptera Simuliidae

Ephemeropte

Ephemeropte

Ephemeropte

Ephemeropte Acentrella

Ephemeropte Anepeorus

Ephemeropte Cercobrachys

Ephemeropte Fallceon

Ephemeropte Heptagenia

Ephemeropte Hexagenia

Ephemeropte Isonychia

Ephemeropte Leucrocuta

Ephemeropte Tricorythodes

Haplotaxida Oligochaeta

Odonata Gomphidae

Odonata

Trichoptera

Trichoptera

Trichoptera
Gomphidae

Cheumatopsyche

Hydropsyche_Cer

Nectopsyche

\section{FinalID:}

Dubiraphia

Cryptochironomus

Polypedilum

Robackia

Hemerodromia

Cricotopus bicinctus $\mathrm{Gr}$.

Simulium

Homoeoneuria alleni

Raptoheptagenia cruentata

Traverella albertana

Acentrella insignificans

Anepeorus rusticus

Cercobrachys

Fallceon quilleri

Heptagenia

Hexagenia limbata

Isonychia

Leucrocuta

Tricorythodes

Tubificidae

Ophiogomphus severus

Stylurus intricatus

Cheumatopsyche

Hydropsyche morosa gr.

Nectopsyche

\section{Individuals}

3

3

2

3

2

21

2

9

35

35

3

4

4

30

16

4

\section{Tol Val: $\quad$ FFG:}

$\mathrm{SC} / \mathrm{CG}$

PR

$\mathrm{SH}$

CG

PR

$\mathrm{CG} / \mathrm{SH}$

CF

CF

PR

CF

$C G$

PR

$C G$

CG

SC

$C G$

CF

SC

CG

CG

PR

PR

CF

unk

$\mathrm{SH}$
Habit:

"CN/50\%, BU/50\%"

$\mathrm{BU} / \mathrm{SP}$

$\mathrm{CN}$

unk

SP

$\mathrm{CN}$

$\mathrm{CN}$

BU

$\mathrm{CN}$

$\mathrm{CN}$

"SW/10\%, CN/90\%"

$\mathrm{CN}$

"SP/75\%, CM/90\%"

"SW/10\%, CN/90\%"

$\mathrm{CN}$

$B U$

SW/CN

$\mathrm{CN}$

CN/SP

$\mathrm{BU}$

unk

unk

$\mathrm{CN}$

$\mathrm{CN}$

$\mathrm{CM} / \mathrm{SP} / \mathrm{CN}$ 
Appendix C. (cont.) Powder River Site 3 @ Jenkins Creek. Targeted-Riffle \& Reach-Wide EMAP

Waterbody Name: Powder River@Jenkins Targeted-Riffle

Station ID: YLBLMPW3T5

\section{Site Classification:}

Order: $\quad$ OTU name:

Basommatop Planorbidae

Coleoptera Microcylloepus

Coleoptera Stenelmis

Diptera Chironominae

Diptera Chironominae

Diptera Hemerodromia

Diptera Simuliidae

Ephemeropte

Ephemeropte

Ephemeropte Acerpenna

Ephemeropte Cercobrachys

Ephemeropte Choroterpes

Ephemeropte Fallceon

Ephemeropte Heptagenia

Ephemeropte Hexagenia

Ephemeropte Isonychia

Ephemeropte Leucrocuta

Ephemeropte Pseudocloeon

Ephemeropte Tricorythodes

Haplotaxida Oligochaeta

Hemiptera Naucoridae

Trichoptera Cheumatopsyche

Trichoptera Hydropsyche_Cer

Trichoptera Nectopsyche

Trombidiform Acarina

$\begin{array}{lc}\text { FinallD: } & \text { Individuals } \\ \text { Gyraulus } & 2 \\ \text { Microcylloepus pusillus } & 1 \\ \text { Stenelmis } & 2 \\ \text { Polypedilum } & 15 \\ \text { Robackia } & 1 \\ \text { Hemerodromia } & 1 \\ \text { Simulium } & 17 \\ \text { Raptoheptagenia cruentata } & 13 \\ \text { Traverella albertana } & 72 \\ \text { Acerpenna } & 1 \\ \text { Cercobrachys } & 4 \\ \text { Choroterpes } & 3 \\ \text { Fallceon quilleri } & 1 \\ \text { Heptagenia } & 2 \\ \text { Hexagenia limbata } & 1 \\ \text { Isonychia } & 4 \\ \text { Leucrocuta } & 3 \\ \text { Pseudocloeon } & 2 \\ \text { Tricorythodes } & 21 \\ \text { Tubificidae } & 1 \\ \text { Ambrysus mormon } & 1 \\ \text { Cheumatopsyche } & 62 \\ \text { Hydropsyche morosa gr. } & 1 \\ \text { Nectopsyche } & 2 \\ \text { Sperchon } & 2\end{array}$

Waterbody Name: Powder River@Jenkins Reach-Wide Station ID:

\section{YLBLMPW305}

\section{Collection Date:}

Tol Val: FFG:

CG

$C G$

$\mathrm{SC} / \mathrm{CG}$

$\mathrm{SH}$

$C G$

$\mathrm{PR}$

$\mathrm{CF}$

PR

$\mathrm{CF}$

$\mathrm{SC}$

CG

$\mathrm{CG}$

$C G$

$\mathrm{SC}$

CG

$\mathrm{CF}$

$\mathrm{SC}$

CG

CG

$C G$

PR

$\mathrm{CF}$

unk

$\mathrm{SH}$

PR
07/11/2005

Habit:

$\mathrm{CN}$

"CN/50\%, BU/50\%"

"CN/50\%, BU/50\%"

$\mathrm{CN}$

unk

SP

$\mathrm{CN}$

$\mathrm{CN}$

$\mathrm{CN}$

"SW/10\%, CN/90\%"

"SP/75\%, CM/90\%"

$\mathrm{CN} / \mathrm{SP}$

"SW/10\%, CN/90\%"

$\mathrm{CN}$

BU

SW/CN

$\mathrm{CN}$

"SW/10\%, CN/90\%"

CN/SP

$\mathrm{BU}$

unk

$\mathrm{CN}$

$\mathrm{CN}$

$\mathrm{CM} / \mathrm{SP} / \mathrm{CN}$

unk

\begin{tabular}{|c|c|c|c|c|c|c|}
\hline $\begin{array}{l}\text { Order: } \\
\text { Basommatop }\end{array}$ & $\begin{array}{c}\text { PTU name: } \\
\text { Planorbidae }\end{array}$ & $\begin{array}{c}\text { FinalID: } \\
\text { Gyraulus }\end{array}$ & $\begin{array}{c}\text { viduals } \\
3\end{array}$ & $\underset{8}{\text { Tol Val: }}$ & $\begin{array}{c}F F G: \\
C G\end{array}$ & $\begin{array}{r}\text { Habit: } \\
\mathrm{CN}\end{array}$ \\
\hline Coleoptera & Microcylloepus & Microcylloepus pusillus & 3 & 5 & CG & "CN/50\%, BU/50\%" \\
\hline Coleoptera & Stenelmis & Stenelmis & 2 & 5 & SC/CG & "CN/50\%, BU/50\%" \\
\hline Diptera & Chironominae & Polypedilum & 7 & 6 & $\mathrm{SH}$ & $\mathrm{CN}$ \\
\hline Diptera & Simuliidae & Simulium & 3 & 5 & CF & $\mathrm{CN}$ \\
\hline Ephemeropte & & Raptoheptagenia cruentata & 5 & 2 & PR & $\mathrm{CN}$ \\
\hline Ephemeropte & & Traverella albertana & 25 & 2 & $\mathrm{CF}$ & $\mathrm{CN}$ \\
\hline Ephemeropte & Acerpenna & Acerpenna & 5 & 4 & SC & "SW/10\%, CN/90\%" \\
\hline Ephemeropte & Cercobrachys & Cercobrachys & 6 & & CG & "SP/75\%, CM/90\%" \\
\hline Ephemeropte & Fallceon & Fallceon quilleri & 5 & 5 & CG & "SW/10\%, CN/90\%" \\
\hline Ephemeropte & Heptagenia & Heptagenia & 5 & 4 & SC & $\mathrm{CN}$ \\
\hline Ephemeropte & Hexagenia & Hexagenia limbata & 1 & 6 & CG & $\mathrm{BU}$ \\
\hline Ephemeropte & Isonychia & Isonychia & 4 & 2 & $\mathrm{CF}$ & $\mathrm{SW} / \mathrm{CN}$ \\
\hline Ephemeropte & Leucrocuta & Leucrocuta & 6 & 1 & SC & $\mathrm{CN}$ \\
\hline Ephemeropte & Tricorythodes & Tricorythodes & 57 & 4 & CG & $\mathrm{CN} / \mathrm{SP}$ \\
\hline Haplotaxida & Oligochaeta & Tubificidae & 1 & 10 & CG & $\mathrm{BU}$ \\
\hline Hemiptera & Naucoridae & Ambrysus mormon & 1 & 3 & PR & unk \\
\hline Trichoptera & Cheumatopsyche & Cheumatopsyche & 84 & 5 & $\mathrm{CF}$ & $\mathrm{CN}$ \\
\hline Trichoptera & Nectopsyche & Nectopsyche & 11 & 2 & $\mathrm{SH}$ & $\mathrm{CM} / \mathrm{SP} / \mathrm{CN}$ \\
\hline
\end{tabular}


Appendix C (cont.). Powder River, Site 5 @ Rough Creek. Targeted-Riffle EMAP

\begin{tabular}{|c|c|c|c|c|c|}
\hline Order & FinallD & Individuals & TolVal & FFG & Habit \\
\hline Diptera & Probezzia & 1 & & PR & $\mathrm{BU} / \mathrm{SW}$ \\
\hline Diptera & Cryptochironomus & 3 & 8 & PR & $\mathrm{BU} / \mathrm{SP}$ \\
\hline Diptera & Polypedilum & 18 & 6 & $\mathrm{SH}$ & $\mathrm{CN}$ \\
\hline Diptera & Hemerodromia & 4 & 6 & PR & SP \\
\hline Diptera & Cricotopus & 1 & 8 & $\mathrm{CG} / \mathrm{SH}$ & $\mathrm{CN}$ \\
\hline Diptera & Simulium & 25 & 5 & CF & $\mathrm{CN}$ \\
\hline Ephemeroptera & Traverella albertana & 199 & 2 & CF & $\mathrm{CN}$ \\
\hline Ephemeroptera & $\begin{array}{l}\text { Raptoheptagenia } \\
\text { cruentata }\end{array}$ & 7 & 2 & PR & $\mathrm{CN}$ \\
\hline Ephemeroptera & Cercobrachys & 27 & & $C G$ & "SP/75\%, CM/90\%" \\
\hline Ephemeroptera & Fallceon quilleri & 8 & 5 & CG & "SW/10\%, CN/90\%" \\
\hline Ephemeroptera & Heptagenia & 1 & 4 & SC & $\mathrm{CN}$ \\
\hline Ephemeroptera & Isonychia & 12 & 2 & CF & SW/CN \\
\hline Ephemeroptera & Leucrocuta & 4 & 1 & SC & $\mathrm{CN}$ \\
\hline Ephemeroptera & Tricorythodes & 13 & 4 & CG & $\mathrm{CN} / \mathrm{SP}$ \\
\hline Haplotaxida & Tubificidae & 1 & 10 & CG & $\mathrm{BU}$ \\
\hline Hemiptera & Ambrysus mormon & 1 & 3 & PR & unk \\
\hline Odonata & Ophiogomphus severus & 3 & 5 & PR & unk \\
\hline Trichoptera & Cheumatopsyche & 87 & 5 & CF & $\mathrm{CN}$ \\
\hline Trichoptera & Hydropsyche morosa gr. & 7 & 6 & unk & $\mathrm{CN}$ \\
\hline Trichoptera & Hydroptila & 1 & 6 & $\mathrm{PH}$ & $\mathrm{CN}$ \\
\hline Trichoptera & Mayatrichia & 1 & 1 & SC & $\mathrm{CN}$ \\
\hline Trichoptera & Nectopsyche & 1 & 2 & $\mathrm{SH}$ & $\mathrm{CM} / \mathrm{SP} / \mathrm{CN}$ \\
\hline Trombidiformes & Sperchon & 1 & & PR & unk \\
\hline
\end{tabular}


Appendix C (cont.). Powder River, Site 6. Targeted-Riffle and Reach-wide EMAP.

\section{Montana Bioassessment Report}

Waterbody Name: Powder River@buttermilk

Station ID: $\quad$ YLBLMPW6T5

Collection Date: 7/12/2005

$\begin{array}{lllcccc}\text { Order: } & \text { OTU name: } & \text { FinalID: } & \text { Individuals } & \text { Tol Val: } & \text { FFG: } & \text { Habit: } \\ \text { Coleoptera } & \text { Hydrobius } & \text { Hydrobius } & 1 & & & \\ \text { Diptera } & \text { Chironominae } & \text { Cryptochironomus } & 11 & 8 & \mathrm{PR} & \mathrm{BU} / \mathrm{SP} \\ \text { Diptera } & \text { Chironominae } & \text { Cryptotendipes } & 12 & 6 & \mathrm{PR} & \mathrm{SP} \\ \text { Diptera } & \text { Chironominae } & \text { Micropsectra } & 1 & 4 & \mathrm{CG} & \mathrm{CN} / \mathrm{SP} \\ \text { Diptera } & \text { Chironominae } & \text { Parachironomus } & 12 & 10 & \mathrm{PR} / \mathrm{CG} / \mathrm{PA} & \mathrm{SP} \\ \text { Diptera } & \text { Chironominae } & \text { Polypedilum } & 5 & 6 & \mathrm{SH} & \mathrm{CN} \\ \text { Diptera } & \text { Chironominae } & \text { Robackia } & 2 & 4 & \mathrm{CG} & \text { unk } \\ \text { Diptera } & \text { Simuliidae } & \text { Simulium } & 11 & 5 & \mathrm{CF} & \mathrm{CN} \\ \text { Ephemeropte } & \text { Raptoheptagenia cruentata } & 2 & 2 & \mathrm{PR} & \mathrm{CN} \\ \text { Ephemeropte } & \text { Traverella albertana } & 98 & 2 & \mathrm{CF} & \mathrm{CN} \\ \text { Ephemeropte Cercobrachys } & \text { Cercobrachys } & 11 & & \mathrm{CG} & \text { "SP/75\%, CM/90\%" } \\ \text { Ephemeropte Heptagenia } & \text { Heptagenia } & 2 & 4 & \mathrm{SC} & \mathrm{CN} \\ \text { Ephemeropte } & \text { Isonychia } & \text { Isonychia } & 3 & 2 & \mathrm{CF} & \mathrm{SW} / \mathrm{CN} \\ \text { Ephemeropte } & \text { Tricorythodes } & \text { Tricorythodes } & 6 & 4 & \mathrm{CG} & \mathrm{CN} / \mathrm{SP} \\ \text { Haplotaxida } & \text { Oligochaeta } & \text { Tubificidae } & 2 & 10 & \mathrm{CG} & \mathrm{BU} \\ \text { Hemiptera } & \text { Naucoridae } & \text { Ambrysus mormon } & 2 & 3 & \mathrm{PR} & \text { unk } \\ \text { Trichoptera } & \text { Brachycentrus } & \text { Brachycentrus occidentalis } & 1 & 2 & \mathrm{CF} & \mathrm{CN} \\ \text { Trichoptera } & \text { Cheumatopsyche } & \text { Cheumatopsyche } & 41 & 5 & \mathrm{CF} & \mathrm{CN} \\ \text { Trichoptera } & \text { Nectopsyche } & \text { Nectopsyche } & 1 & 2 & \mathrm{SH} & \mathrm{CM} / \mathrm{SP} / \mathrm{CN}\end{array}$

Waterbody Name: Powder River@buttermilk Reach-wide EMAP

Station ID:YLBLMPW605

\begin{tabular}{|c|c|c|c|c|c|c|}
\hline $\begin{array}{l}\text { Order: } \\
\text { Coleoptera }\end{array}$ & $\begin{array}{l}\text { OTU name: } \\
\text { Stenelmis }\end{array}$ & $\begin{array}{l}\text { FinalID: } \\
\text { Stenelmis }\end{array}$ & $\underset{2}{\text { ndividuals }}$ & $\underset{5}{\text { Tol Val: }}$ & $\begin{array}{c}\boldsymbol{F} \boldsymbol{F G}: \\
\text { SC/CG }\end{array}$ & $\begin{array}{l}\text { Habit: } \\
\text { "CN/50\%, BU/50\%" }\end{array}$ \\
\hline Diptera & Chironominae & Cryptotendipes & 1 & 6 & PR & SP \\
\hline Diptera & Chironominae & Micropsectra & 5 & 4 & CG & $\mathrm{CN} / \mathrm{SP}$ \\
\hline Diptera & Chironominae & Polypedilum & 12 & 6 & $\mathrm{SH}$ & $\mathrm{CN}$ \\
\hline Diptera & Chironominae & Robackia & 2 & 4 & CG & unk \\
\hline Diptera & Hemerodromia & Hemerodromia & 2 & 6 & PR & SP \\
\hline Diptera & Simuliidae & Simulium & 3 & 5 & $\mathrm{CF}$ & $\mathrm{CN}$ \\
\hline Ephemeropte & & Neochoroterpes oklahoma & 1 & & unk & $\mathrm{CN} / \mathrm{SP}$ \\
\hline Ephemeropte & & Raptoheptagenia cruentata & 3 & 2 & PR & $\mathrm{CN}$ \\
\hline Ephemeropte & & Traverella albertana & 42 & 2 & $\mathrm{CF}$ & $\mathrm{CN}$ \\
\hline Ephemeropte & Acerpenna & Acerpenna & 15 & 4 & SC & "SW/10\%, CN/90\%" \\
\hline Ephemeropte & Cercobrachys & Cercobrachys & 51 & & CG & "SP/75\%, CM/90\%" \\
\hline Ephemeropte & Fallceon & Fallceon quilleri & 5 & 5 & CG & "SW/10\%, CN/90\%" \\
\hline Ephemeropte & Heptagenia & Heptagenia & 6 & 4 & SC & $\mathrm{CN}$ \\
\hline Ephemeropte & Hexagenia & Hexagenia limbata & 4 & 6 & CG & $\mathrm{BU}$ \\
\hline Ephemeropte & Isonychia & Isonychia & 3 & 2 & $\mathrm{CF}$ & $\mathrm{SW} / \mathrm{CN}$ \\
\hline Ephemeropte & Pseudocloeon & Pseudocloeon & 1 & 4 & CG & "SW/10\%, CN/90\%" \\
\hline Ephemeropte & Tricorythodes & Tricorythodes & 10 & 4 & CG & $\mathrm{CN} / \mathrm{SP}$ \\
\hline Hemiptera & Naucoridae & Ambrysus mormon & 9 & 3 & PR & unk \\
\hline Odonata & Gomphidae & Stylurus & 2 & 2 & PR & unk \\
\hline Plecoptera & Acroneuria & Acroneuria abnormis & 1 & 2 & PR & $\mathrm{CN}$ \\
\hline Trichoptera & Cheumatopsyche & Cheumatopsyche & 76 & 5 & $\mathrm{CF}$ & $\mathrm{CN}$ \\
\hline Trichoptera & Nectopsyche & Nectopsyche & 9 & 2 & $\mathrm{SH}$ & $\mathrm{CM} / \mathrm{SP} /$ \\
\hline
\end{tabular}


Appendix C. (Cont.). Macroinvertebrate metrics and plains MMI calculations. T=Targeted-Riffle, and RW=Reach-Wide EMAP

\begin{tabular}{|c|c|c|c|c|c|c|c|c|c|c|c|c|c|c|}
\hline StationID: & WaterbodyName: & CollDate: & Totallnd: & Plains Index & EPT Tax & $\begin{array}{c}\text { EPT } \\
\text { TaxScP }\end{array}$ & $\begin{array}{c}\text { Tanypod } \\
\text { Pct }\end{array}$ & $\begin{array}{c}\text { Tanypod } \\
\text { PctScP }\end{array}$ & $\begin{array}{c}\text { Orth2 } \\
\text { MidgPct }\end{array}$ & $\begin{array}{c}\text { Orth2Midg } \\
\text { PctScP }\end{array}$ & $\begin{array}{c}\text { Predator } \\
\text { Tax }\end{array}$ & $\begin{array}{l}\text { Predator } \\
\text { TaxScP }\end{array}$ & Filt CollPct & $\begin{array}{c}\text { Filt } \\
\text { CollPctS } \\
\mathrm{cP}\end{array}$ \\
\hline YLBLMPW105 & Powder River 1@WY RW & 11-Jul-05 & 295 & 58.10 & 14.00 & 100.00 & & 0.00 & & 100.00 & 5.00 & 55.56 & 77.29 & 34.94 \\
\hline YLBLMPW1T5 & Powder River1@WY T & 11-Jul-05 & 597 & 57.02 & 10.72 & 76.54 & & 0 & 12.5 & 87.5 & 4.56 & 50.7 & 54.27 & 70.35 \\
\hline YLBLMPW2T5 & Powder River 2@drycreek T & 11-Jul-05 & 613 & 52.29 & 10.25 & 73.24 & & 0.00 & 28.57 & 71.43 & 4.28 & 47.54 & 54.98 & 69.27 \\
\hline YLBLMPW205 & Powder River 2@drycreek RW & 11-Jul-05 & 257 & 49.17 & 12.00 & 85.71 & & 0.00 & 25.00 & 75.00 & 4.00 & 44.44 & 73.54 & 40.71 \\
\hline YLBLMPW3T5 & Powder River3@Jenkins T & 11-Jul-05 & 235 & 60.16 & 13.00 & 92.86 & & 0.00 & & 100.00 & 4.00 & 44.44 & 58.72 & 63.50 \\
\hline YLBLMPW305 & Powder River3@Jenkins RW & 11-Jul-05 & 234 & 46.36 & 10.00 & 71.43 & & 0.00 & & 100.00 & 2.00 & 22.22 & 75.21 & 38.13 \\
\hline YLBLMPW505 & Powder River 5RW & 12-Jul-05 & 246 & 65.36 & 12.00 & 85.71 & 1.63 & 16.26 & & 100.00 & 6.00 & 66.67 & 62.20 & 58.16 \\
\hline YLBLMPW5T5 & Powder River 5T & 12-Jul-05 & 426 & 60.50 & 9.81 & 70.07 & & 0.00 & 4.55 & 95.45 & 5.08 & 56.44 & 47.65 & 80.53 \\
\hline YLBLMPW6T5 & Powder River6@buttermilk T & 12-Jul-05 & 224 & 49.00 & 7.00 & 50.00 & & 0.00 & & 100.00 & 2.00 & 22.22 & 52.68 & 72.80 \\
\hline YLBLMPW605 & Powder River6@buttermilk RW & 12-Jul-05 & 265 & 57.28 & 11.00 & 78.57 & & 0.00 & & 100.00 & 5.00 & 55.56 & 66.04 & 52.25 \\
\hline
\end{tabular}


Appendix D. Macroinvertebrate EMAP protocol comparisons with Percent Community Similarity and Taxa Similarity per site.

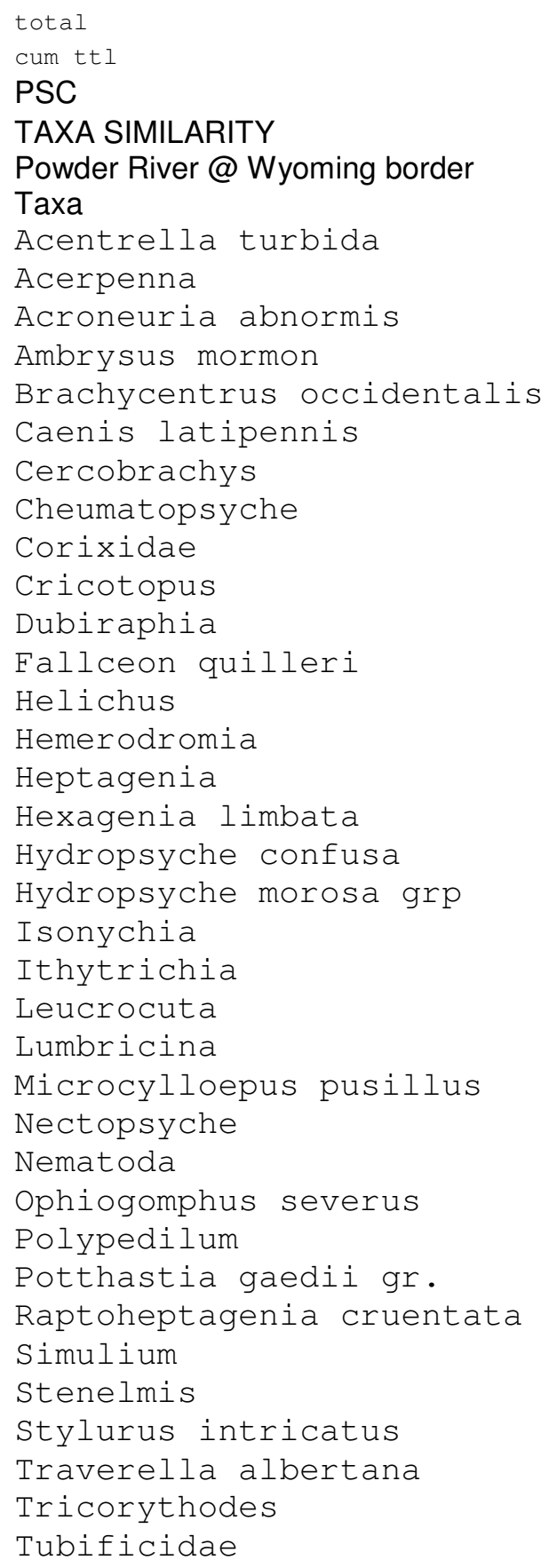

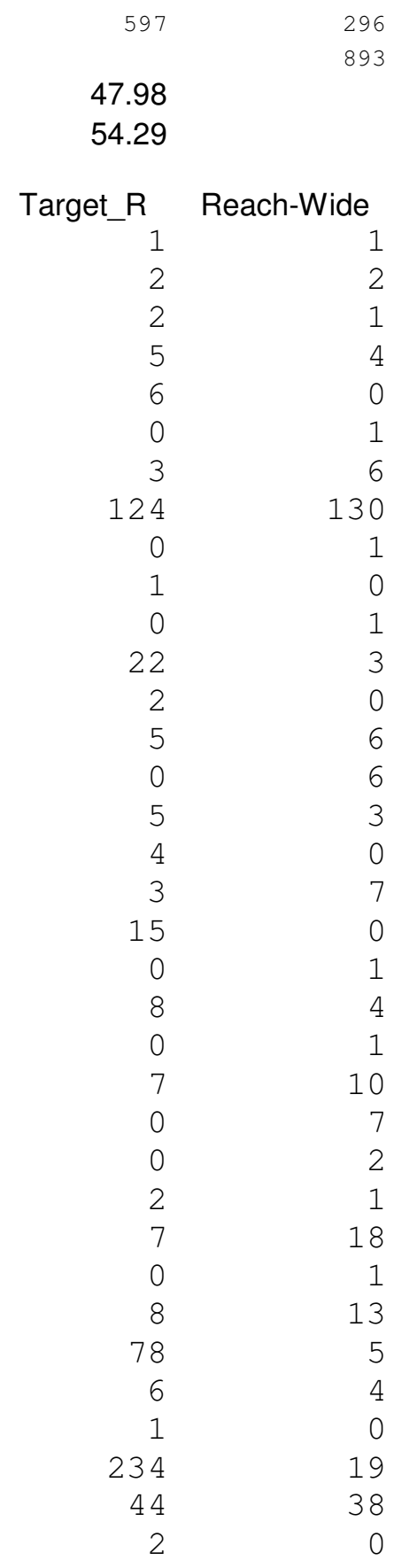


Appendix D. (cont.) Macroinvertebrate EMAP protocol comparisons with Percent Community Similarity and Taxa Similarity per site.

\begin{tabular}{|c|c|c|}
\hline total & 613 & 257 \\
\hline cum ttl & & 870 \\
\hline PSC & 51.62 & \\
\hline TAXA SIMILARITY & 41.67 & \\
\hline Powder River \& Dry Creek S & e 2 & \\
\hline Taxa & Target_R & Reach-Wide \\
\hline Acentrella insignificans & 0 & 1 \\
\hline Acentrella turbida & 1 & 0 \\
\hline Anepeorus rusticus & 0 & 2 \\
\hline Acroneuria abnormis & 2 & 0 \\
\hline Ambrysus mormon & 2 & 0 \\
\hline Brachycentrus occidentalis & 1 & 0 \\
\hline Cercobrachys & 3 & 41 \\
\hline Cheumatopsyche & 105 & 30 \\
\hline Cricotopus bicinctus gr. & 0 & 2 \\
\hline Cryptochironomus & 0 & 3 \\
\hline Dubiraphia & 0 & 1 \\
\hline Fallceon quilleri & 12 & 9 \\
\hline Helichus & 1 & 0 \\
\hline Hemerodromia & 5 & 3 \\
\hline Heptagenia & 0 & 3 \\
\hline Hexagenia limbata & 12 & 4 \\
\hline Homoeoneuria alleni & 0 & 2 \\
\hline Hydropsyche confusa & 1 & 0 \\
\hline Hydropsyche morosa grp & 16 & 16 \\
\hline Isonychia & 8 & 1 \\
\hline Leucrocuta & 4 & 4 \\
\hline Microcylloepus pusillus & 3 & 0 \\
\hline Nectopsyche & 0 & 4 \\
\hline Ophiogomphus severus & 3 & 2 \\
\hline Orthocladius & 1 & 0 \\
\hline Parakiefferiella & 1 & 0 \\
\hline Polypedilum & 5 & 1 \\
\hline Potamyia flava & 2 & 0 \\
\hline Raptoheptagenia cruentata & 14 & 9 \\
\hline Robackia & 0 & 2 \\
\hline Simulium & 125 & 21 \\
\hline Stenelmis & 2 & 0 \\
\hline stylurus intricatus & 0 & 4 \\
\hline Traverella albertana & 244 & 35 \\
\hline Tricorythodes & 38 & 56 \\
\hline Tubificidae & 2 & 1 \\
\hline
\end{tabular}


Appendix D. (cont.) Macroinvertebrate protocol comparisons with Percent Community Similarity and Taxa Similarity per site.

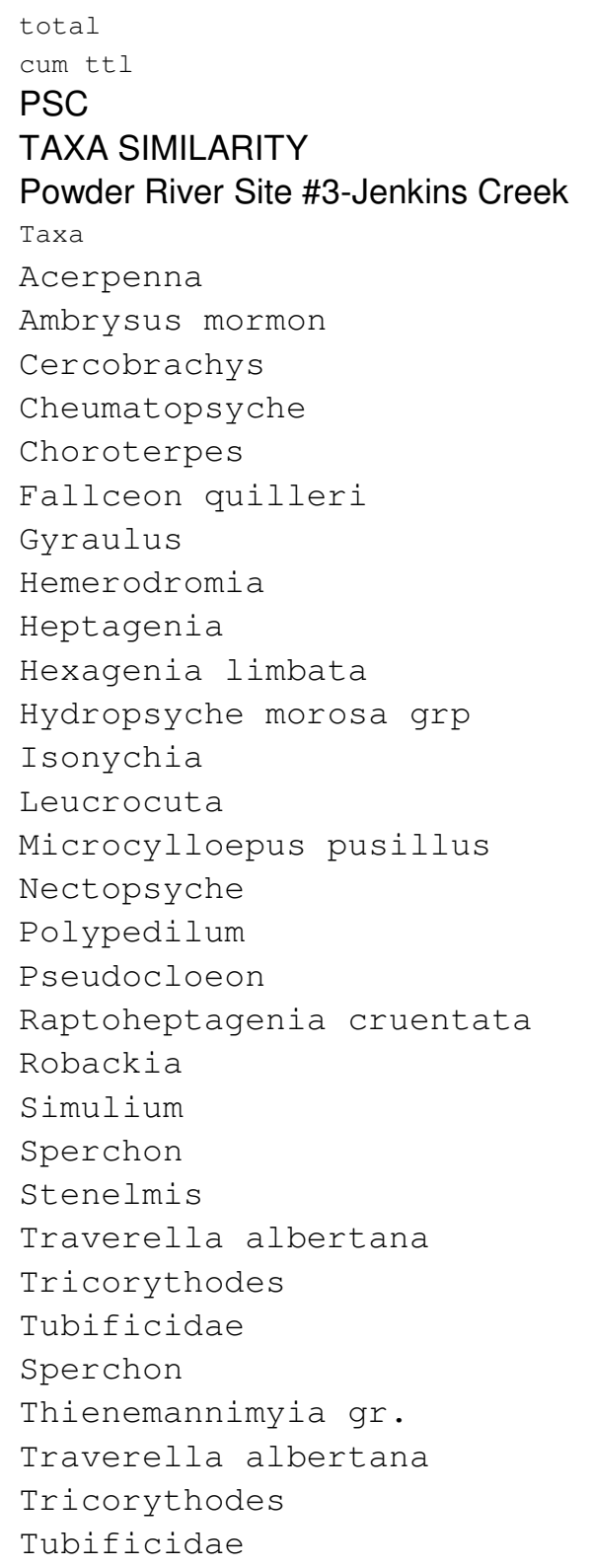

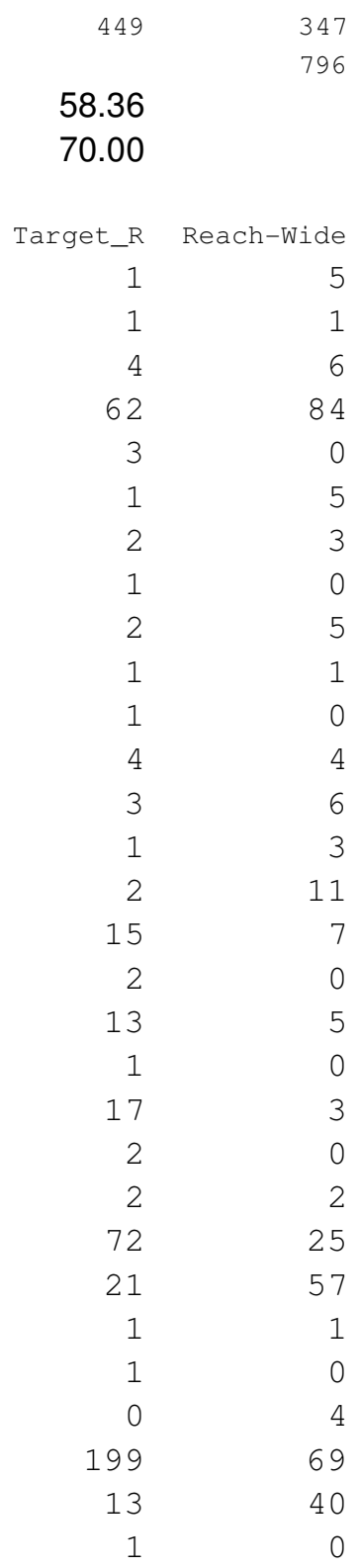


Appendix D. (cont.) Macroinvertebrate protocol comparisons with Percent Community Similarity and Taxa Similarity per site.

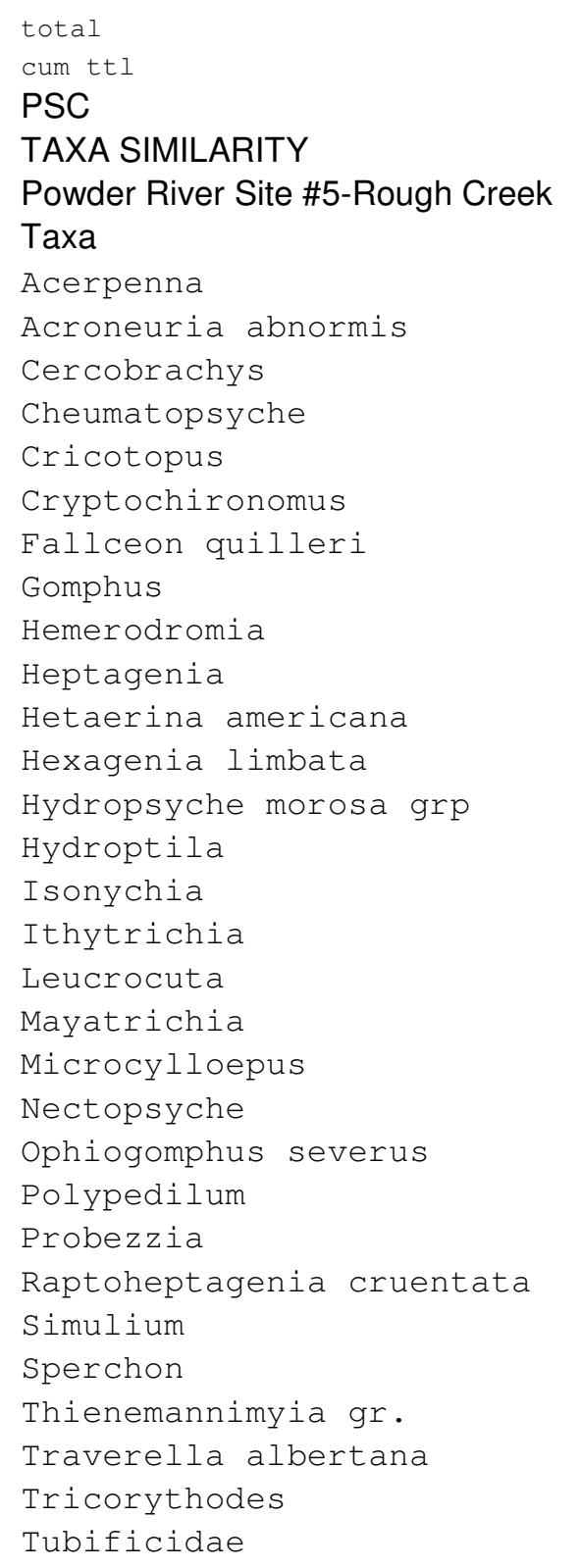

\begin{tabular}{|c|c|}
\hline 425 & $\begin{array}{l}246 \\
671\end{array}$ \\
\hline 64.80 & \\
\hline 40.00 & \\
\hline Target_R & Reach-Wide \\
\hline 0 & 2 \\
\hline 0 & 1 \\
\hline 27 & 20 \\
\hline 87 & 29 \\
\hline 1 & 0 \\
\hline 3 & 0 \\
\hline 8 & 5 \\
\hline 0 & 1 \\
\hline 4 & 0 \\
\hline 1 & 5 \\
\hline 0 & 1 \\
\hline 0 & 2 \\
\hline 7 & 0 \\
\hline 1 & 0 \\
\hline 12 & 5 \\
\hline 0 & 2 \\
\hline 4 & 2 \\
\hline 1 & 0 \\
\hline 0 & 1 \\
\hline 1 & 6 \\
\hline 3 & 0 \\
\hline 18 & 33 \\
\hline 1 & 1 \\
\hline 7 & 0 \\
\hline 25 & 17 \\
\hline 1 & 0 \\
\hline 0 & 4 \\
\hline 199 & 69 \\
\hline 13 & 40 \\
\hline 1 & 0 \\
\hline
\end{tabular}


Appendix D. (cont.) Macroinvertebrate protocol comparisons with Percent Community Similarity and Taxa Similarity per site.

\begin{tabular}{|c|c|c|}
\hline \multicolumn{3}{|l|}{ total } \\
\hline cum ttl & & 489 \\
\hline PSC & 50.94 & \\
\hline TAXA SIMILARITY & 50.00 & \\
\hline \multicolumn{3}{|l|}{ Powder River Site \#6-Buttermilk Creek } \\
\hline Taxa & Target_R & Reach-Wide \\
\hline Acerpenna & 0 & 15 \\
\hline Acroneuria abnormis & 0 & 1 \\
\hline Ambrysus mormon & 2 & 9 \\
\hline Brachycentrus occidentalis & 1 & 0 \\
\hline Cercobrachys & 11 & 51 \\
\hline Cheumatopsyche & 41 & 76 \\
\hline Cryptochironomus & 11 & 0 \\
\hline Cryptotendipes & 12 & 1 \\
\hline Fallceon quilleri & 0 & 5 \\
\hline Hemerodromia & 0 & 2 \\
\hline Heptagenia & 2 & 6 \\
\hline Hexagenia limbata & 0 & 4 \\
\hline Hydrobius & 1 & 0 \\
\hline Isonychia & 3 & 3 \\
\hline Micropsectra & 1 & 5 \\
\hline Nectopsyche & 1 & 9 \\
\hline Neochoroterpes oklahoma & 0 & 1 \\
\hline Parachironomus & 12 & 0 \\
\hline Polypedilum & 5 & 12 \\
\hline Pseudocloeon & 0 & 1 \\
\hline Raptoheptagenia cruentata & 2 & 3 \\
\hline Robackia & 2 & 2 \\
\hline Simulium & 11 & 3 \\
\hline Stenelmis & 0 & 2 \\
\hline Stylurus intricatus & 0 & 2 \\
\hline Traverella albertana & 98 & 42 \\
\hline Tricorythodes & 6 & 10 \\
\hline Tubificidae & 2 & 0 \\
\hline
\end{tabular}


Appendix E. Fish and Macroinvertebrate Community Group Descriptions (Stagliano 2005).

Group SPA \#2- Medium Warmwater River Assemblage. Most of the medium to large warmwater river cyprinid species occur in this species assemblage (flathead chub, Platygobio gracilis; sand shiner, Notropis stramineus; plains minnow, Hybognathus placitus; western silvery minnow, Hybognathus argyritis), as well as the Catastomids: shorthead redhorse (Moxostoma macrolepidotum) and river carpsucker (Carpiodes carpio). Introduced species associated with this assemblage are the exotic carp (Cyprinus carpio), the plains killifish, green sunfish (Lepomis cyanellus) and black bullhead (Ameiurus melas). This species assemblage occurs in many of the Medium Prairie Rivers of Montana, the freeflowing, undamned sections of the Missouri River, and is the integral assemblage of the Powder River, which includes the MT species of concern Sturgeon Chub. The channel catfish and stonecat could easily co-occur within SPA 1 or 2 if proper habitat requirements are met, such as deep, side channel pools and large structures for hiding (large cobbles, boulders or woody debris).

\section{Large Prairie River Macroinvertebrate Community:}

This community consists of members of the Large Prairie River and Filtering Collector Assemblage in the riffles, and the Large River Slow Current and Medium River Side-Channel Assemblages in the slow current and side channels areas, and the special sand-dwelling mayfly community group in the vast sandbar areas of the Powder River. The community indicator species are characterized by main channel riverine dragonfly species, Stylurus and Ophiogomphus, the mayflies- Neochoroterpes oklahoma, Choroterpes, Camelobatidius, Fallceon quilleri, Acentrella insignificans, Ephoron album, Travarella albertana, the caddisflies-Icthythrichia, Psychomyia, Hydropsyche morosa group, Cheumatopsyche, sidechannel Hemiptera, the Corixidae, Ambrysus mormon-and the freshwater mussels- the fatmucket (Lampsilus siliquiodea) and the giant floater (Pyganodon grandis).

Group 37 - Filtering-Collector Assemblage-This moderately tolerant macroinvertebrate group is associated with warm-water medium and large rivers $\left(4^{\text {th }}-7^{\text {th }}\right.$ order $)$ of low elevation $(2000-3500 \mathrm{ft})$, low forest cover, high-linkages, high nutrient/turbidity and moderate gradient (slow-moderate current velocity) with stable $\rightarrow$ shifting substrates. This community occurs in silt/sand/gravel substrates of large rivers (A001, A003, B006) or smaller (C007) degraded streams with sediment and nutrient problems. Two indicator taxa, Simulium and Hydropsyche confusa, can quickly colonize newly exposed substrates, so shifting sediments will not greatly disturb this community. Most of the indicator taxa are filterercollectors or predators and can tolerate streams with higher agricultural and sediment influences than most other large stream/ river communities.

Stream and river examples: Frenchman Creek, Battle Creek, West Fork Poplar, Little Missouri, Powder River. Other indicator taxa: Isonychia, Stylurus, Eukiefferella claripennis grp and Pseudocloeon

Group SDM- Large River, Sand-Dwelling Mayfly Assemblage- This rare community type is rarely collected in traditional bioassessment samples due to their fast swimming abilities (i.e. net avoidance) and occurrence on extensive sandbars where typical samples are not taken. This community is associated with the largest class of rivers in the classification (5th -7 th order) that are low elevation, low to moderate gradient with shifting sandbars and islands with side channels. River representatives include the Powder River and the lower Missouri and Yellowstone Rivers where suitable habitat exists. This large-river group has highly-specialized and globally rare indicator species: Analetris eximia, Lachlania saskatchewanensis, Anepeorus rusticus, Ametropus neavei and Homoeoneuria alleni, and are closely associated with species from the Large Prairie River Assemblage that occur in the riffle or other stable substrate areas. Raptoheptegenia cruentata is a member of this group but favors cobble riffles with an underlying sandy substrate. 